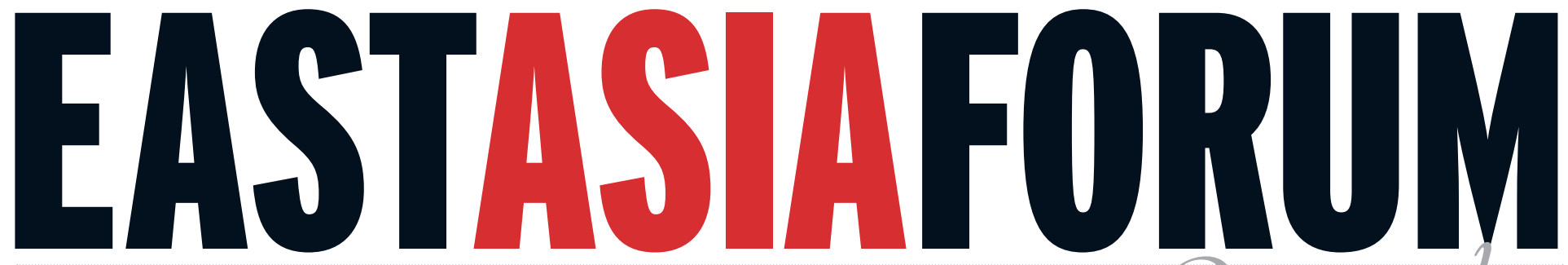

ECONOMICS, POLITICS AND PUBLIC POLICY IN EAST ASIA AND THE PACIFIC Vol.13 No.3 July-September $2021 \$ 9.50$
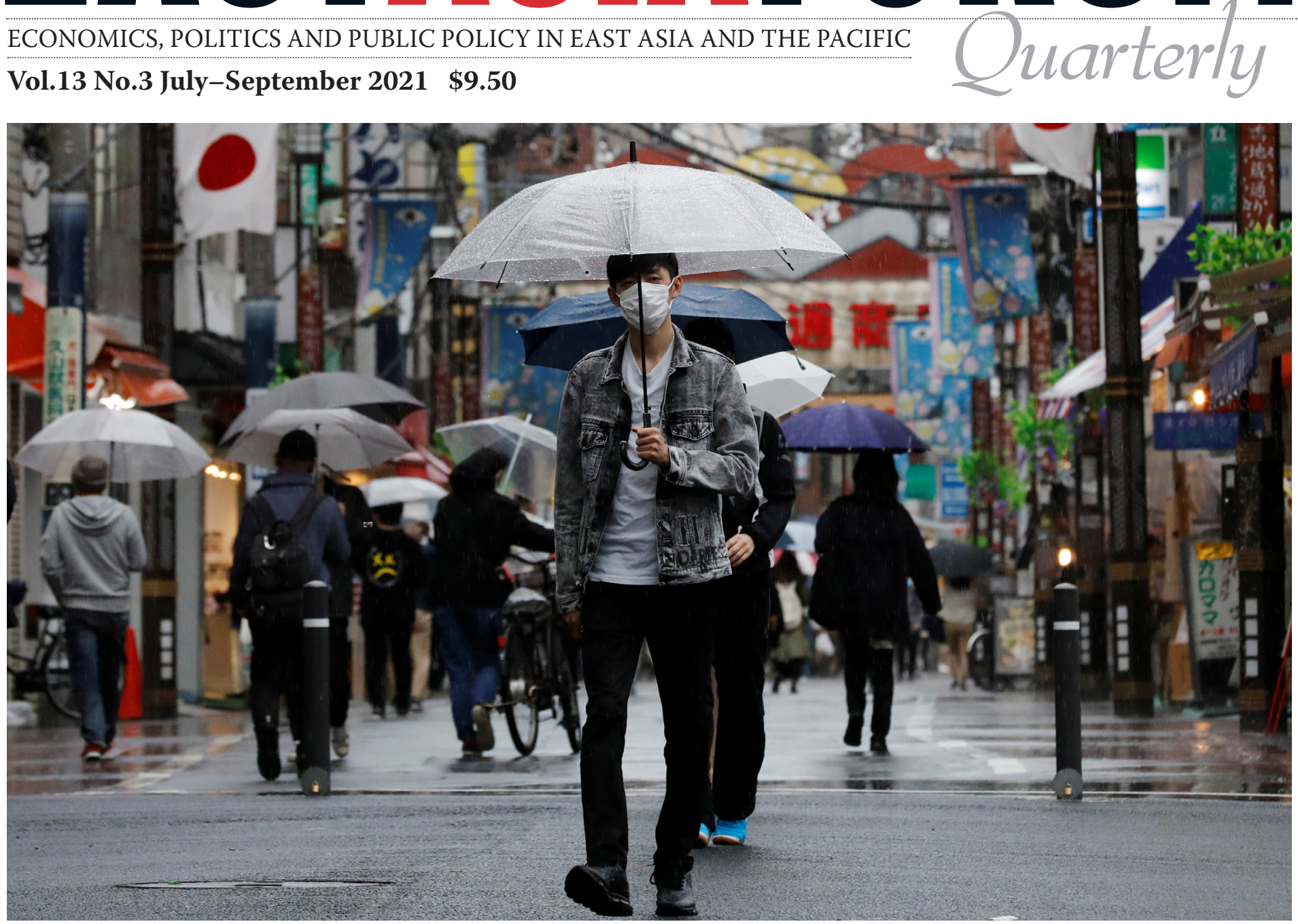

\title{
Confronting crisis in Japan
}

Sheila Smith Managing China-Taiwan tensions

Kumiko Nemoto Japan's imperial succession

Lawrence Repeta The Diet's constitutional authority

Jun Mukoyama A new agency for digitalisation ... and more

ASIAN REVIEW: Kerry Brown on the Indo-Pacific construct 


\section{EASTASIAFORUM \\ Quarterly \\ ISSN $1837-5081$ (print) \\ ISSN 1837-509X (online)}

\section{From the Editor's desk}

In 2021, Japan took on a load that few other nations would contemplate: hosting the Olympic games during a global pandemic. This fiendish circumstance inevitably put a spotlight on Japan's crisis governance capabilities. Whether it be in the sphere of social issues, domestic political economy or foreign policy, Japan's capacity to manage 'slow-burn' crises will be the primary test for the country's policymakers and citizens alike in coming years.

This issue of East Asia Forum Quarterly examines the array of crises that Japan confronts in the 21st century. We begin with the most immediate crisis facing Japan and the world, the COVID-19 pandemic, and examine it from political, economic, Olympic, constitutional and social capital perspectives. COVID-19 has brought to the fore the need for Japan properly to embrace digital technology in its governance processes.

In the era of \#MeToo, the conundrum of Japan's Imperial succession remains problematic and the underwhelming outcomes of 'womenomics' are underscored by ongoing demographic decline. Politically, the prospect of a competitive democratic landscape is still a remote prospect and learning from previous crises only grows in importance.

In foreign policy, whether the Japan-US alliance is fit for purpose is likely to be revealed in the event of a crisis in the region. In managing international crises, the prospect of one involving Taiwan or Japan's broken relationship with South Korea are front of mind.

In confronting crisis, Japan's capacity for creative rethinking will have to partner with social resilience to find a pathway through lingering, befuddling crises across the policy spectrum.

Our Asian Review section takes a sceptical look at whether the IndoPacific idea can meet the rising expectations that appear to be held of it and examines the devastating impact of COVID-19 on India, and how federalism affected its management of the crisis and public trust in government.

\section{Rikki Kersten and Ben Ascione}

COVER PHOTO: A man wearing a protective face mask, amid the COVID-19 pandemic, walks along a local shopping street in Tokyo (May 2021). Picture: Kim Kyung-Hoon / Reuters.

\section{CONTENTS}

3 RIKKI KERSTEN

Can Suga rise above caretaker?

5 IPPEI FUJIWARA

Dealing with Japan's uncertain fiscal outlook

\section{BEN ASCIONE}

Suga's bet on Olympic gold

\section{JUN MUKOYAMA}

New agency to accelerate Japan's digitalisation

11 SHEILA A. SMITH

Managing China-Taiwan tensions

14 LAUREN RICHARDSON

A new logic of cooperation for Japan-South Korea relations

16 KERRY BROWN

ASIAN REVIEW: The Indo-Pacific construct and the reality of Chinese power

22 NIRANJAN SAHOO \& AMBAR KUMAR GHOSH

ASIAN REVIEW: COVID-19 exposes India's fragile federalism

\section{DANIEL ALDRICH}

The benefits of social infrastructure and civic ties in uncertain times

\section{JUSTIN WHITNEY}

A new mantra for Japanese disaster management

30 LAWRENCE REPETA

The Diet's constitutional authority

32 CHELSEA SZENDI SCHIEDER

Reconciling population and social expectations

35 JIRO YAMAGUCHI

LDP dominance still cripples Japanese democracy

37 KUMIKO NEMOTO

Reflecting modern Japan in the imperial succession 


\section{TAKING CARE OF POLITICS}

\section{Can Suga rise above caretaker?}

\section{RIKKI KERSTEN}

T IS ironic that in the time

of COVID-19, democratic governments are judged according to how quickly and pervasively they impose constraints on their societies in the name of public health. For voters, competent management of the pandemic has become a vital criterion for reward or punishment at the polls.

This context is politically tricky to manage on its own. Add hosting the Olympics during a pandemic, as a transitional leader, and you enter the unique world of political pain that is the lot of Japan's Prime Minister Yoshihide Suga.

Suga acquired the mantle of leadership from Japan's longestserving prime minister, Shinzo Abe, in September 2020 following Abe's decision to step down from the prime ministership and presidency of the Liberal Democratic Party (LDP) for health reasons. By then Abe had already confronted shattering disappointments that cruelled the political legacy he envisaged for himself: the postponing of the Tokyo 2020 Olympics and the resurgence of COVID-19, both of which damaged Japan's economic prosperity and Abe's own popularity.

With the prospect of a poor showing at Japan's general election, due by 21 October this year, it seemed a good idea to transfer power over to a steady hand. No one's hand could be steadier than that of Suga, who was the longest-serving chief cabinet secretary

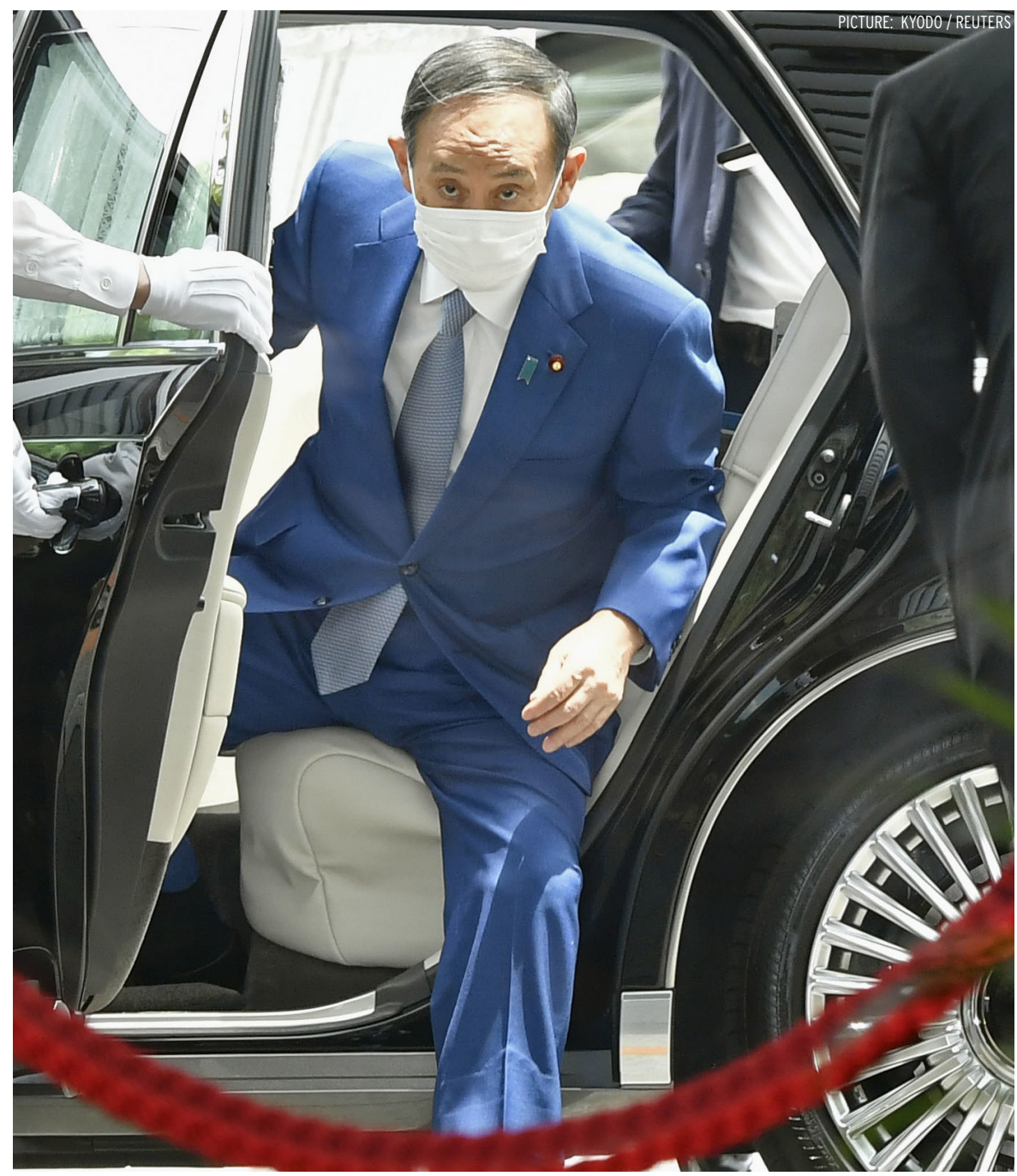

Prime Minister Yoshihide Suga has shown his credentials in the inverted universe of pandemic democracy.

in Japanese history, and Abe's second in command.

Described by Titli Basu as 'the indispensable architect of the Abe administration', Suga's tenure commenced in a procedural context of democratic compromise. Unlike normal times, Suga's presidency of the LDP - and thus the prime ministership-was subject only to a vote of the parliamentary party members, not also that of the rank and file members. It is this, plus the short amount of time remaining in the electoral cycle, that brands Suga with the label of transitional leader.

This view was further entrenched when Suga declared in his first policy speech that his goal was to continue the policies of the Abe government, 


\section{EASTASIAFORUM EDITORIAL STAFF}

Issue Editors

Rikki Kersten, Honorary Professor at The Australian National University and Professor Emerita of Murdoch University.

Ben Ascione, Assistant Professor at the Graduate School of Asia-Pacific Studies, Waseda University.

\section{Series Editors}

Peter Drysdale, Editor in Chief, East Asia Forum and Head, East Asian Bureau of Economic Research, Crawford School of Public Policy, ANU.

Shiro Armstrong, Director, AustraliaJapan Research Centre, and Editor, East Asia Forum, Crawford School of Public Policy, ANU.

\section{Editorial Staff}

Coordination: Arius Derr, Kira Atkins.

Editing: Marie Armstrong, David Chieng, Benjamin Clarke, Hannah Dixon, Oliver Friedmann, Annie Gao, Brandon Harrington, Alexi Heazle, Grace King, James Naylor-Pratt, Maya Salama, David Wu, ANU.

Editorial Advisers: Max Suich, Peter Fuller.

Production: Niki van den Heuvel Email Peter.Drysdale@anu.edu.au, Shiro.Armstrong@anu.edu.au.

Views expressed are those of individual authors and do not represent the views of the Crawford School, ANU, EABER, EAF, or the institutions to which the authors are attached.

\section{ANU PRESS}

Published by ANU Press The Australian National University Canberra ACT 2601, Australia Email: anupress@anu.edu.au Web: http://press.anu.edu.au which initially featured successfully containing COVID-19 and revitalising the economy.

Becoming prime minister in September 2020 was crazy brave. Leadership aspirants Fumio Kishida, Taro Kono and Shigeru Ishiba all had stronger factional bases - and they still do, with the exception of Ishiba whose factional numbers have declined-but they ceded the poisoned chalice to Suga. Suga, who is a master political tactician, took that chalice, and cleverly allocated substantive cabinet roles to his rivals. Burdened with the ignominy of the Diamond Princess cruise ship debacle, Suga's challenge in continuing Abe's policies had to begin with restoring credibility to government.

In terms of COVID-19 vaccinations, the report card for Suga was 'must try harder': procurement of vaccines was slow, and logistical obstaclesmobilising sufficient medical personnel and insisting on additional vaccine testing in Japan-held up the vaccine rollout. The burden of COVID-19 on hospital intensive care units in Japan's ageing society is another performance measure that Suga will continue to struggle with as Delta takes hold.

But Suga had two other millstones around his neck.

First, under the terms of the Act on Special Measures for Pandemic Influenza and New Infectious Diseases Preparedness and Response, the measures available to government to control the spread of the virus relied on voluntary constraints on business and wider society. Initially, financial incentives and compensation for businesses that closed early, or closed altogether, made the running. This was in accord with the hubris that prevailed in Japan in early 2020 about the 'Japanese model' of virus

control, which had delivered relatively low rates of infection and death in Japan compared to other advanced countries.

Second, Suga forged ahead with the GoTo Travel campaign which entailed government subsidies for domestic travel to stimulate economic recovery. He has since been forced by spikes in infections to temporarily suspend the program on four occasions. Abe's shadow also darkened Suga's prospects through lingering scandal in the LDP, forcing two of the three by-elections held in April this year. The LDP lost all three, not even attempting to run in the third race. The Tokyo municipal election in July likewise saw a less than stellar showing for the LDP-Komeito coalition.

$\mathbf{S}$ UGA'S responses reveal a core of grim determination that goes beyond the acts of a caretaker prime minister. On 3 February this year, the Japanese Diet's upper house passed the Suga administration's amended Act on Special Measures for Pandemic Influenza and New Infectious Diseases Preparedness and Response after only 10 days of deliberation. This enabled provincial governers to apply punitive measures, such as fines, to businesses which did not comply with restrictions, and to individuals who refused to be hospitalised.

Suga even engaged in massive overreach as he attempted to persuade banks to apply pressure to businesses that did not agree to stop serving alcohol during Japan's fourth wave of infections. As sticks replaced carrots, Suga rode a wave of condemnation as newspaper editorials called for the Olympics to be cancelled. The President of the International Olympic Committee, Thomas Bach, declared that the Olympics would go ahead even if a state of emergency were 


\section{CLOSING THE CROCODILE'S JAWS}

declared in Tokyo, as it was on 8 July.

Ultimately, Suga will confront the same predicament as other democratic leaders - he will be judged according to his COVID-19 record. As far as vaccination rates are concerned, recent polling indicates that Suga is toast: Japan has one of the lowest vaccination rates in the OECD, though as of mid-August Suga had rapidly improved Japan's standing in the global vaccination league table.

With the electoral cycle following hard on the heels of the Paralympics, it is hard to see who else would want to sit in the prime ministerial hot seat as the pandemic continues to rage around Japan. A new leader will have no time to sell themselves to voters before going to the ballot box. No matter who leads the coalition to the polls, it is likely that, thanks to COVID-19, the LDP will lose its super majority in parliament as voters exact their revenge.

Suga has shown his credentials in the inverted universe of democracy during a global pandemic, in taking hard measures that severely restrain rights and freedoms.

If the timing of the LDP presidential election shifts to after Japan's general election, and the Olympics have somehow managed to bring sufficient joy to an alienated and distanced populace Suga may fly in the face of conventional political logic and emerge triumphant. He will then be a leader of a party in democratic dudgeon, but back in office in spite of it all. EAFO

Rikki Kersten is Honorary Professor at The Australian National University and Professor Emerita of Murdoch University.

\section{Japan's uncertain fiscal outlook}

IPPEI FUJIWARA

C OVID-19 has had a substantial adverse effect on the Japanese economy. This is not only in terms of supply shocks such as lockdowns and the suspension of business activities, but also in terms of demand shocks from drops in income and the resulting hits to consumer sentiment. But COVID has also had some potential positive effects. The spread of remote work could lead to improvements in Japanese work style and increase efficiency. It is still difficult to foresee what kind of impact these changes will have on the Japanese economy in the longer run. Forecasts indicate that the economic downturn is severe but cyclical, and that the economy will return to growth near its potential rate in 2-3 years.

One problem that has come into sharper focus during the current COVID-19 crisis is fiscal sustainability. Japan's budget deficit has been growing since the economy fell into decline in the 1990s, with government expenditure and revenue diverging from each other. Visual representation of this widening gap is said to resemble the open jaws of a crocodile, and led to coining of the Japanese term 'crocodile mouth'. Due to COVID-19, the crocodile's jaws are said, metaphorically speaking, to have come off.

Fiscal stimulus is certainly needed to smooth out the economic downswing in response to a crisis like COVID-19. But the jaws of the crocodile cannot keep expanding forever. Accumulated debt will continue to grow if government expenditure grows faster than government revenues, and it will not be easy to formulate a clear path to close the fiscal gap in the future.

Though there have been warnings that huge government debt might cause issues such as hyperinflation and surges in nominal interest rates, these problems have yet to materialise. The fact that inflation and nominal interest rates have remained low in a country like Japan-where the debt-toGDP ratio is outstandingly high even by global standards-has reinforced the view that the crocodile's mouth isn't a big deal. Some say the situation resembles that of the boy who cried wolf.

Even from a theoretical point of view, it is difficult to gauge when and at what level the fiscal situation will become unsustainable. Large debt is not a problem if future net tax revenue grows to cover it. As long as the public believes that the level of debt will settle down some time in the future-no matter how many years it takes-fiscal sustainability can be maintained without the inflation of interest burden it threatens. Expectations, of course, are rather difficult to gauge.

It is also difficult to calculate what the optimal level of debt might be. Few people would think that the optimal debt balance is zero. Whatever it is will depend crucially on the appetite for government bonds. The issue of government bonds allows 
governments a line of credit but also plays an essential role as collateral for smooth financial transactions, because of their unique value as a safe asset.

The role of government bonds in enhancing financial transactions is akin to the role of money-utterly worthless in itself but in reality traded as something that represents value. Similarly, the value of government bonds as safe assets and financial instruments is not necessarily fixed and stable but varies depending on economic conditions. This makes it difficult to measure the optimal level of debt-we can say that it is positive, but we do not know how much of it is positive.

If the optimal debt-to-GDP ratio is above the current level, then the crocodile's mouth may remain open for a while yet. Though it cannot remain open forever, some factors will continue to shift the upper jaw further upwards, at least over the next few years as the COVID downturn persists.

Japan also has one of the world's most remarkably advanced ageing populations. Within a few years, the country will enter an era of 'superageing'.

Between 2018 and 2025 the population aged $65-74$ will decrease by 2.63 million, from 17.6 million to 14.97 million, while the number of people aged 75 and over will increase by 3.82 million, from 17.98 million to 21.8 million, according to Japan's Ministry of Finance. As a result, medical and nursing care costs are expected to increase substantially. Compared to the 65-74 age group, for those aged 75 and over, the per capita cost of medical care will be around four times higher and the cost of nursing care 10 times higher.

How should Japan solve this fiscal problem, and how can it ensure fiscal sustainability? Any policy that sharply raises the crocodile's lower jaw (lifts revenues) will entail heavy short-term costs in the middle of a pandemicinduced downturn. The voters are unlikely to wear a shift in that policy direction. Since the ratio of older people in the electorate is high and the voting turnout of younger people is low, the rational calculations of politicians will favour the elderly.

The difficulty of knowing what the optimal debt level is, and the extent of austerity and when it may be needed, prompt postponement of immediate action and forward strategies that might solve the problem-making it only more difficult to reach a solution when the day of reckoning finally comes. EAFO

Ippei Fujiwara is Professor at the Crawford School of Public Policy, The Australian National University and Faculty of Economics, Keio University, and Research Fellow at CEPR and Fellow at the Asian Bureau of Finance and Economic Research.

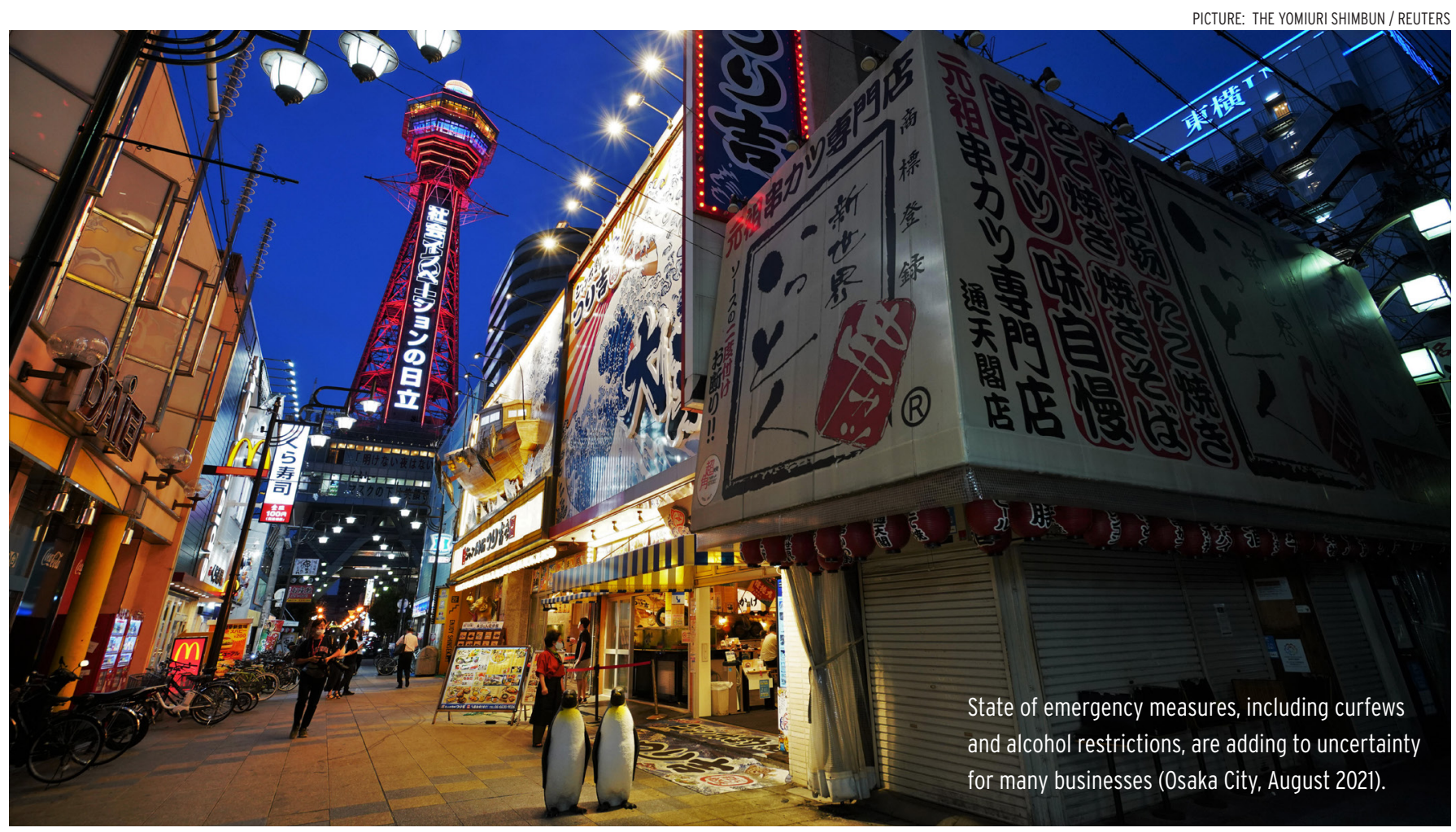

6 EAST ASIA FORUM QUARTERLY JULY - SEPTEMBER 2021 


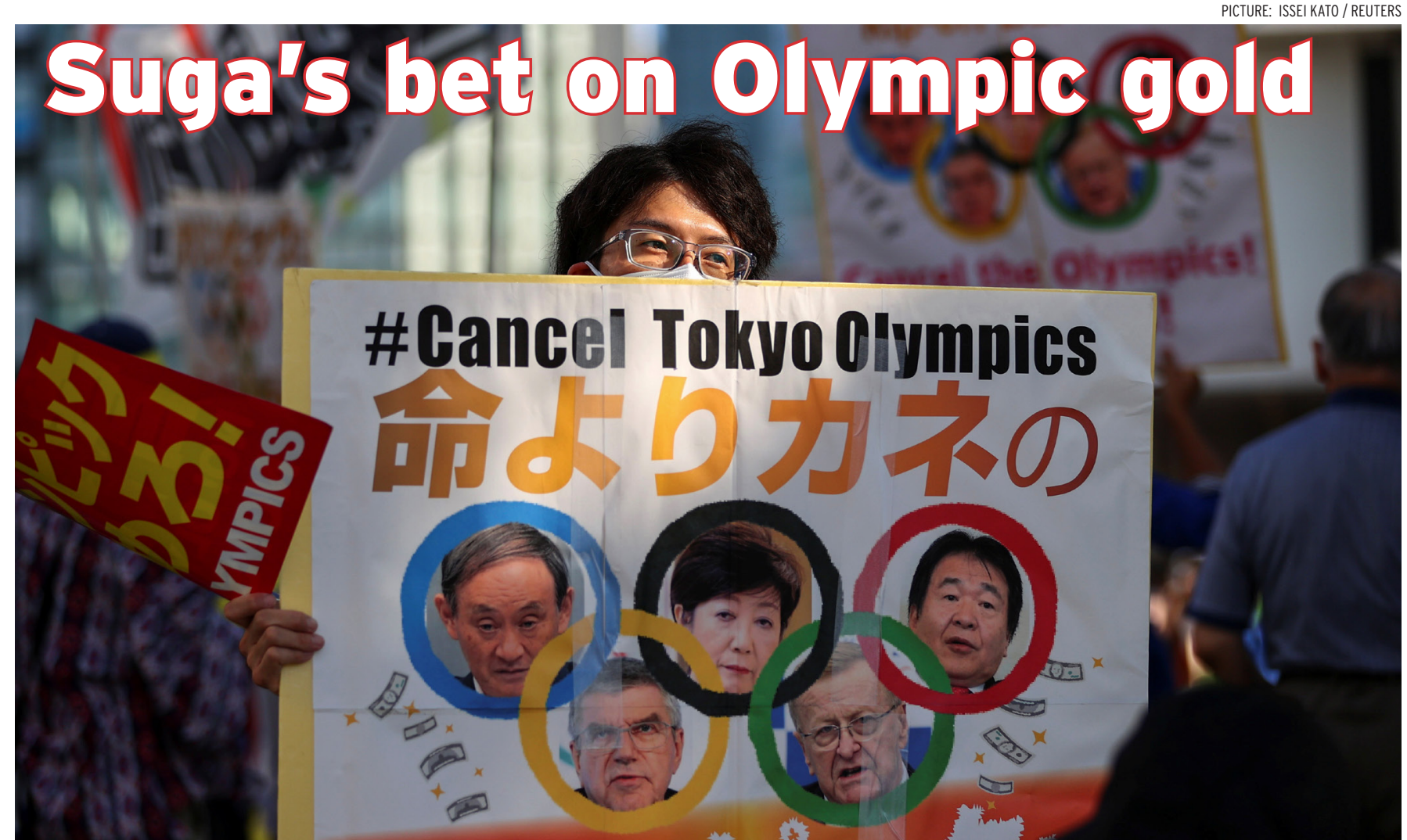

An anti-Olympics protestor displays a banner emblazoned with \#Cancel Tokyo Olympics and The Olympics puts money ahead of human life (trans.) in Tokyo's Shinjuku district (August 2021).

\section{BEN ASCIONE}

\section{$\mathbf{T}$} HE Olympic and Paralympic Games are among the most complex, large-scale and international events in the world, involving over 15,000 athletes and tens of thousands of contingent personnel from more than 200 countries. So as audiences around the world tuned in to watch Tokyo 2020, they may have been wondering why Japan decided to host the event despite the ongoing COVID-19 pandemic.

Prime Minister Yoshihide Suga's decision to hold the Games on schedule, under the one-year postponement plan inherited from the Abe administration, revolved around his need to face a Liberal Democratic Party (LDP) leadership election in September and a lower-house election by October. Part of Suga's calculus was the weak state of Japan's opposition parties, which have never recovered from a loss of trust during the nowdefunct Democratic Party of Japan's short stint in power between 2009 and 2012, and low levels of voter turnout in recent elections. Holding the Games was intended to protect Suga, who lacks a strong factional base in the LDP, from the bigger threat of internal challengers.

The critical question was what level of infection control and vaccinations were needed to safely hold the Games without stretching Tokyo's medical system? And what sort of measures would prevent spill over infections from the 'Olympic bubble'? When pressed for details the Suga government repeated the mantra that Japan would hold a 'safe and secure'
Games, sought to evade establishing definitive criteria for success and moved the goal posts when new information came to light.

On infection rates, the head of the Tokyo Medical Association, Haruo Ozaki, suggested in May that Tokyo needed to bring its cases down to at least 100 per day to recover from its fourth wave and safely hold the Games-advice that was ignored. A simulation presented at a Tokyo Olympic Organising Committee expert roundtable in June predicted that infections in Tokyo would increase to about 1000 per day in late August if the Games went ahead, compared with 800 a day if they were postponed or cancelled. A Tokyo Metropolitan Government monitoring meeting in July estimated that daily 


\section{Tokyo has avoided a}

worst-case scenario of

a global super-spreader

event and a 'Tokyo

Olympic variant' of the

virus

infections would reach 2400 (on a

7-day moving average) by 11 August.

These two scenarios were both

thought to be acceptable.

On vaccinations, Japan was too slow to reach anywhere near herd immunity before the Games. It was the slowest among the G7 to procure vaccines while its rollout ranked 33 out of 38 OECD countries when the Games opened.

Medical experts questioned the integrity of the Olympic bubble in the lead up to the Olympics. With about 80 per cent of athletes, media and International Olympic Committee officials vaccinated and 30,000 COVID-19 tests conducted per day during the Games, the bubble was reasonably successful in limiting infections to the hundreds-rather than thousands-and preventing clusters.

But problems managing volunteers and local contractors, who commuted in and out of the bubble on public transport, were never resolved. Despite the Tokyo 2020 Playbooks' strict regulations, many volunteers had reportedly not undergone COVID-19 testing. The Japanese government made vaccination available to volunteers from 30 June-not leaving enough time for most of them to get a second dose. Olympics Minister Tamayo Marukawa was criticised for her 'unscientific' comments when she claimed that one dose would give volunteers 'primary immunity'.

In the weeks leading up to the Games, Tokyo had already entered its fifth wave. A fourth state of emergency was declared and the decision was made to ban domestic spectators. The record for daily infections in Tokyo more than doubled to a new high of over 5000 during the Games and continued to rise to over 5700 a week later. Nationally, daily infections surged from a pre-Games fourth wave high of 7900 in April, to over 15,000 during the Games and 20,000 the week after the Games.

The number of COVID-19 patients in Tokyo awaiting guidance on hospital admission spiked from less than 2500 at the opening of the Games to over 13,000 as the Games closed, overturning the previous record of 7700 during Tokyo's third wave in January. With medical facilities in Tokyo and other prefectures pushed to their limit, the government announced new measures so that only patients at high risk of developing 'severe symptoms'-such as those needing ventilators-would be eligible for hospitalisation.

One reason for the surge of infections surrounding the Olympics was the spread of the Delta variant. Sample screenings of positive COVID-19 cases in Tokyo show that Delta accounted for less than 5 per cent of cases at the start of June, over 20 per cent at the start of July, over 60 per cent in late July and almost 90 per cent the week the Games closed in early August.

The Suga government and Tokyo 2020 organisers painted the rise in infections as unrelated to the Games, emphasising that cases within the bubble were 'within expectations'. The government also argued that Olympic
$\mathrm{TV}$ ratings were encouraging people to stay at home and decrease foot traffic. Yet contact tracing of cases between the bubble and the public was so politically sensitive that transparency was a problem. The government was found to have withheld information about an Olympic accredited official testing positive in Japan's first case of the Lambda variant from Peru a few days before the Games.

While the emergence of the Delta variant, delays in the vaccine rollout and public fatigue with repeated states of emergency all contributed to Tokyo's surge in cases, the Olympics added fuel to the fire. Japan's COVID-19 mitigation strategy relies on the public following voluntary government requests. Holding the Olympics, coupled with requests for people to stay at home under the state of emergency, resulted in confused public messaging and a diminished sense of urgency as people held Olympic viewing parties and crowded outside venues to peek in on the sporting action.

Despite the deterioration in its COVID-19 situation, Tokyo avoided a worst-case scenario of a global superspreader event and a 'Tokyo Olympic variant' of the virus. Yet the final cost to the health of the people of Tokyo is still unclear as the city prepares to do it all again for the Paralympics.

Although Japan celebrated a record Olympic medal haul, Suga's bet to bask in Olympic gold didn't pan out. Whatever marginal political boost there's been from the Olympics has been dwarfed by public concern over the distraction of the government from its handling of the COVID-19 crisis.

Ben Ascione is Assistant Professor at the Graduate School of Asia-Pacific Studies, Waseda University. 


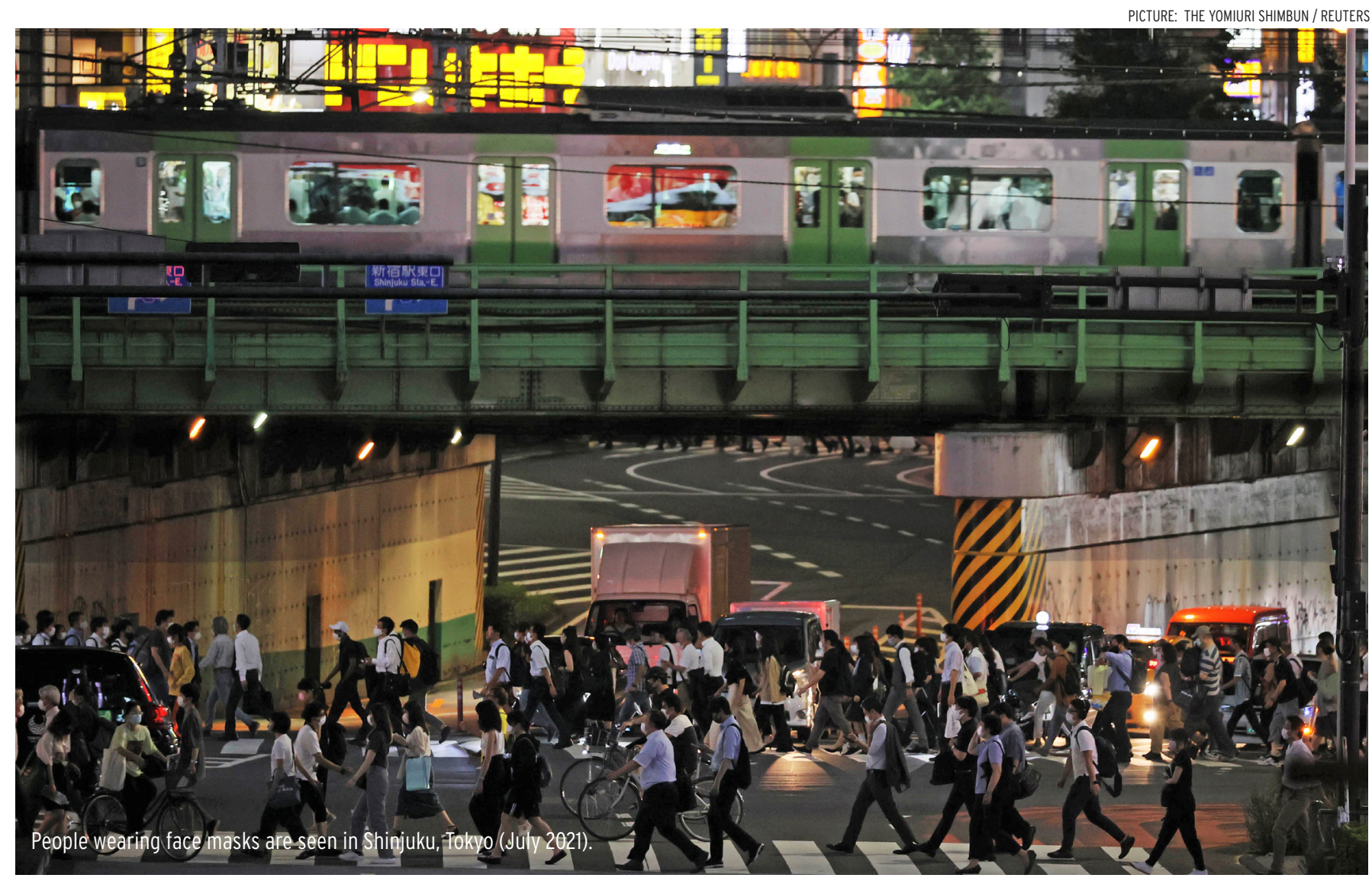

\section{COVID-19 and digital transformation}

JUN MUKOYAMA

\section{A \\ NEWLY established digital agency was unveiled in Japan} on 1 September 2021. The agency, located in an Akasaka skyscraper, is unprecedented in every way. Under the direct supervision of Prime Minister Yoshihide Suga, with 120 of its 500 officials hired from the private sector, the new agency has the authority to manage IT system budgets across Japanese government ministries.

Compared with many of its Western peers, Japan managed the COVID-19 crisis relatively well given its population size and ageing population. But there was one critical aspect of outbreak management in which Japan failed: the effective use of data and technology. In July 2020, then health minister Katsunobu Kato lamented that the greatest challenge in responding to the COVID-19 crisis was the 'delay in digital transformation'. Creating the agency was one of Suga's key policy pledges from day one of his administration. It was designed to overcome 'the defeat in the digital war'. The new digital agency carries the heavy burden of wiping away the stain of this failure.

For many countries, technology plays an essential part in fighting the pandemic. In Japan, technology has been a weakness, not a strength. COVID-19 response experts from Japan's health ministry faced difficulties collecting accurate and real-time data, such as the number of cases and vacant hospital beds. Precious time and resources were used to confirm numbers with local authorities by telephone and manually input data into computers. Fax machines were used to exchange 
hand-written information among medical institutions, regional publichealth centres and local governments. Japanese local governments spent months delivering cash grants to their citizens while developed countries such as Germany, South Korea and the United States swiftly-sometimes in a matter of days-completed payments using digital platforms.

System developments during the pandemic often failed. The Health Center Real-Time Information-Sharing on COVID-19 system hastily built by the health ministry to collect real-time patient data, was criticised for its poor usability, as medical establishments were required to input more than 100 data points when scarcity of resources was the core issue. The COVID-19 Contact-Confirming Application was left incompatible with Android operating system updates for months. An online system that was introduced to accept applications for employment adjustment subsidies was suspended immediately after launch. In order for local governments to conduct vaccination programs, Japanese local government officials needed four different systems in place: an individuals' records management system called the Vaccination Record System, a vaccine allocation system, local government ledgers and a vaccine distribution system.

W HY did a seemingly high-tech country face these challenges? Aside from simply getting rid of fax machines-a move recently ordered by the administrative reform ministerthe Japanese government has to overcome a number of fundamental issues.

First, the government was hindered by insufficient in-house capabilities to manage digitisation. Software development is often outsourced to

\section{The COVID-19 crisis has}

\section{dramatically exposed}

\section{Japan's failed digital}

\section{transformation}

third-party vendors without proper knowledge and oversight. One of the reasons the government lacks internal capabilities is its personnel practice: procurements are managed by career bureaucrats, most of whom have a background in law or the social sciences. The accumulation of their professional knowledge is hampered due to frequent rotation within government agencies in shortterm cycles of two years. Under the lifetime employment culture, the government has very a small number of mid-career employees. The digital agency's hiring of external experts on an unprecedented scale is thus an important milestone in improving its human resources pool and building digital capabilities.

Second, ministries have become silos incapable of building collective strategies or systems that best serve their users. In addition to vertically segmented ministries and agencies, local and national governments have poor data compatibility and coordination. Although the government created a post of Government Chief Information Officer in 2013 to oversee system procurement across ministries, the position lacked authority and resources. It will be a challenge for the new digital agency, which was given significant authority to consolidate the overall IT budget to manage and coordinate different entities effectively.

Finally, the Japanese government needs to work out how to use personal identification numbers-the socalled My Number system-more effectively. Currently, the design of policy programs is constrained by legal obligations relating to the use of My Number. For instance, the government cannot use My Number, which is used for tax filing, to identify those in need of a cash transfers. Additionally, My Number is not linked to bank accounts into which a payment for each individual can be made, thereby requiring cumbersome clerical work at municipal offices to distribute money. The inflexibility and narrow scoping of the My Number law limits the government's ability to implement its policies swiftly and efficiently using digital tools. The new agency must gain the trust of citizens and explain the benefits of using My Number and how the agency intends to address privacy concerns.

This month, the new digital agency will carry a huge burden. It must tackle the issues it faces with strong political leadership, legal authority and talent from the private sector. Fortunately, rage over the failure of Japan's digitisation has ignited a call for change and the agency has strong support from the Japanese public as well as the information technology industry. The agency's open recruitment from the private sector was also highly competitive, with an application-to-job-opening ratio tenfold over.

The COVID-19 crisis has dramatically exposed Japan's failed digital transformation. Nowhere is the need or reward for digitising processes greater than in the business of the Japanese government. EAFQ

Jun Mukoyama is a Fellow at the Asia Pacific Initiative. 


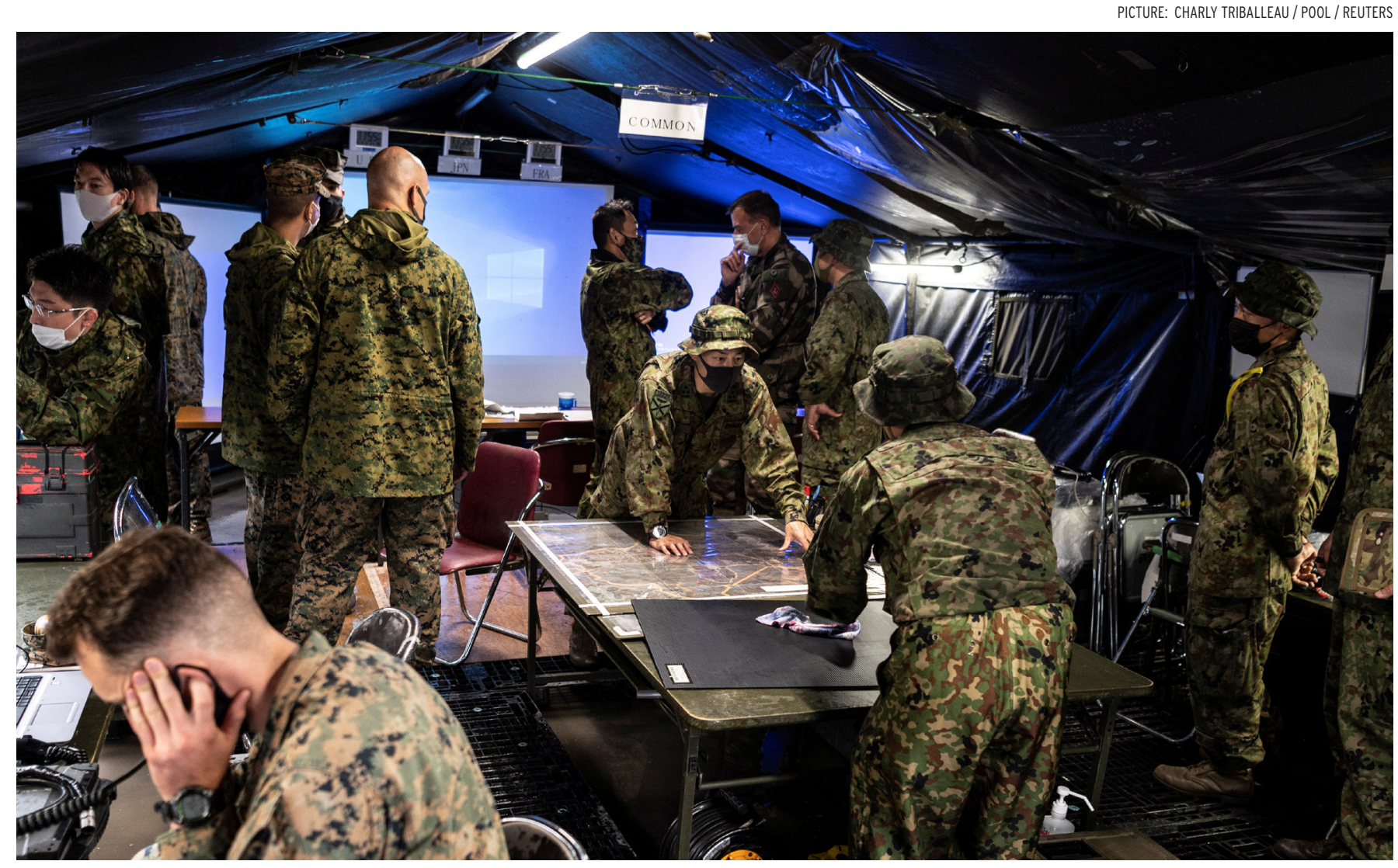

Japanese soldiers and US Marines train during a joint military drill held at Japan's Kirishima Exercise Area in Ebino, Miyazaki Prefecture (May 2021).

\section{Managing China-Taiwan tensions}

\section{SHEILA A. SMITH}

$\mathbf{T}$

ODAY, Beijing has far greater military resources to bring to bear on its relations with its neighbours, and increasing pressure on Taiwan's defences by the Chinese People's Liberation Army (PLA) has many in Washington and Tokyo worried about Beijing's intentions. China is now the top priority for the US-Japan alliance, as the foreign and defence secretaries and cabinet ministers of both nations made clear in their joint statement for the JapanUS Security Consultative Committee

\section{$(2+2)$ in March 2021.}

A month later, Japanese Prime Minister Yoshihide Suga and US President Joe Biden also called out China for its behaviour, raising concerns about human rights issues, maritime challenges across the region and economic coercion imposed on trading partners. But their statement'We underscore the importance of peace and stability across the Taiwan Strait and encourage the peaceful resolution of cross-Strait issues' suggests renewed allied concern about rising tensions there.

Japan will have no choice but to prepare to defend itself in the case of a conflict across the Taiwan Strait. Proximity to Taiwan-only a hundred or so kilometres separate Taiwan from Japan's southernmost islands-makes the possibility of conflict there of deep interest to Japan's Self-Defense Forces (SDF). In addition, Okinawa hosts a considerable array of US military forces, making it a likely staging area for any US assistance to Taiwan's defences. 


\section{China remains one of}

\section{Japan's largest trading}

partners and the PLA

\section{regularly operate in and}

\section{through Japan's waters}

\section{and airspace}

Japanese Deputy Prime Minister Taro Aso testified to the Diet on 5 July that a military crisis across the Taiwan Strait would threaten Japan's survival. This was a nod to the 2015 security laws that laid the groundwork for the SDF to join with other national militaries in case of a conflict.

But the consequences of Tokyo's decision-making on Taiwan will be grave. China remains one of Japan's largest trading partners and the PLA regularly operate in and through Japan's waters and airspace. Politics in Japan and China are sensitive to any perception of military threat. Already, Chinese government and social media outlets have begun to respond to Japanese government statements on Taiwan. They have made it clear that popular wrath will be directed at Japan should an alliance effort to coordinate on crisis management become more defined for military coordination.

The regional military balance around Japan has been shifting in China's favour. The clash between Beijing and Tokyo over a longdormant sovereignty dispute over islands in the East China Sea a decade ago suggested that China was willing to use its maritime forces, both coast guard and navy, in support of its territorial claims. Japan's defence planners have watched with growing concern as China builds up military bases on disputed islands in the South China Sea.

$\mathbf{T}$ HE Free and Open Indo-Pacific framing of Japan's strategic aims has thus involved diplomatic, economic and military tools of statecraft. In addition to increasing US-Japan defence cooperation, Tokyo supported the Philippines as it requested arbitration on China's maritime assertions under the United Nations Convention on the Law of the Sea, and urged the Obama Administration to challenge Beijing's upending of the maritime status quo. Former president Donald Trump's direct challenge to China was welcomed by the Fourth Abe Cabinet as was the congressionally driven Pacific Deterrence Initiative to provide greater US military capabilities to the region. But enhanced cooperation between the United States, Japan, Australia and India has also increased Japan's security partnerships, particularly in the maritime domain.

Military action by China against Taiwan would provoke the United States into a military response. Many experts argue that China has little to gain from a direct attack on Taiwan. Yet, outgoing Indo-Pacific commander Admiral Philip Davidson told the US Congress that he thought the PLA would be able to launch such an attack within the next six years. A US response to Chinese aggression against Taiwan would be calibrated to the nature of that threat. Chinese pressure on Taiwan could present itself as greyzone tactics or as cyberattacks. Both could create unprecedented challenges to Taiwan's economic vitality and territorial integrity.

Regardless of the intensity of such a confrontation, Tokyo would be faced with difficult decisions about how Japanese and US forces would cooperate in response. Japan's role in such an imagined scenario would likely involve two distinct actions. First, Japan would be asked to provide support for US operations. Second, Japan's Self-Defense Forces would need to consider how best to defend Japanese territory during a conflict.

The former scenario would necessitate an understanding between Tokyo and Washington on the use of Japan's bases and facilities by US forces. In the past, this allied understanding has largely focused on a Korean contingency. But the specific demands of a Taiwan contingency would need closer consultation between the two governments on how US forces would move through Japan in case of a conflict. Planning for the defence of Japan in case of a crossStrait conflict would need to consider how the SDF will ensure territorial integrity while also providing rear area support for US forces.

Not surprisingly, opinion within Japan is divided. There are those who believe that Japan must play a role with the United States should China use force against Taiwan. Defence ministry officials clearly see a need to develop more clarity on how the alliance would respond. Minister of Defence Nobuo Kishi travelled to Yonaguni Island, the closest Japanese island to Taiwan, while Prime Minister Suga visited Washington DC.

Also, Kishi's political deputy, State Minister of Defence Yasuhide Nakayama, has repeatedly declared to the media that it is time to 'wake up' regarding Taiwan. The newly released 2021 Defence White Paperwhich drew considerable attention for its anime-inspired samurai on the 
cover-clearly stated that cross-Strait tensions were an important factor in considering Japan's security.

$\mathbf{P}$ OLITICAL leaders, even those within the Liberal Democratic Party, are unsure of what steps to take next. Prime Minister Suga has taken a more reserved stance than his deputy. With the Summer Olympics and rising numbers of COVID-19 cases on his hands, this may not be the time to focus on such a difficult set of issues. Rumours of factional strife within the party may also be a factor. They suggest that rhetoric may be getting ahead of the deeper policy review required to consider how Taiwan tensions can be managed in Japanese security planning. Sharing US and Japanese assessments of Chinese behaviour across the Taiwan Strait fully and in the vicinity of Japanese territory is indispensable, but care must be taken to ensure the politics of the moment take a back seat to the need for alliance readiness.

Alliance consultations will move ahead by year's end, and Japan should be prepared to develop its options in three areas.

First, Tokyo should move quickly to decide which bases and facilities in its territory would be freely available to US forces in case of a Taiwan contingency. Ensuring a successful US response to an overt challenge to Taiwan by China will be vital to the alliance response.

Second, in the next US-Japan 2+2, Japanese officials should confirm that Washington and Tokyo understand each other's priorities and reaffirm the principles for joint military action agreed upon in the 2018 Guidelines for Japan-US Defense Cooperation. Specificity will be important here, as the US and Japanese militaries will need to reframe their combined military exercises to ensure smooth coordination in case the PLA continues to expand the scope of its operations.

Third, the SDF will want to clarify the pressures on its defence capabilities should military tensions across the Taiwan Strait grow. Signalling now, Japan's commitment to act in concert with the United States in case of conflict would go a long way towards communicating how civilian authorities in Tokyo would act in a worst-case scenario.

Preventing a crisis may be Tokyo's best approach. In addition to ensuring deterrence against the possibility that China will use force, Japan's strengths, like those of the United States, lie in a strategy to deter such a crisis. Here, Japan has many options.

First, a serious strategy of diplomatic coalition building with the aim of ensuring Taiwanese autonomy would go a long way towards signalling Japanese intent. Japan must consider its own demonstration of official support for the government in Taipei and build diplomatic coalitions that similarly acknowledge Taiwan's need for international support. Already, Japanese diplomats have consulted with partners around the globe on how to manage Chinese pressure. In Europe, parliamentarians openly welcome meetings with Taiwanese representatives, and the G7 has followed the US-Japan lead in voicing concern over the escalation of pressure on Taiwan.

Second, Japan may have deep economic ties with China, but that does not preclude enhancing trade and investment ties with Taiwanese firms. Japan-Taiwan trade is about one-tenth that of Japan-China trade, and avenues for growth should be

\section{Alliance consultations}

will move ahead by

year's end, and Japan

should be prepared to

develop its options in

\section{three areas}

pursued. The recent decision by Taiwan Semiconductor Manufacturing Company (TSMC) to build a factory in Japan is a case in point. A free trade agreement with Taipei would be an important signal of Japan's economic commitment.

Third the 24 million people who live on the island of Taiwan should have the strength of Japanese support for their democracy and autonomy. Tokyo can and should speak out openly and without reservation about its shared interests and longstanding friendship with Taipei.

And finally, the relationship between Japan's next generation and their neighbours must be strengthened. Younger Taiwanese can surely be included in regional efforts to build stronger ties between the future leaders across the Indo-Pacific. The Global Cooperation and Training Framework recently launched by the United States, Japan and Taiwan is an excellent example of the kind of initiatives that will ensure the Taiwanese people can continue to look forward to a prosperous and secure future. EAFO

Sheila A. Smith is John E. Merow Senior Fellow for Asia Pacific studies at the Council on Foreign Relations. 


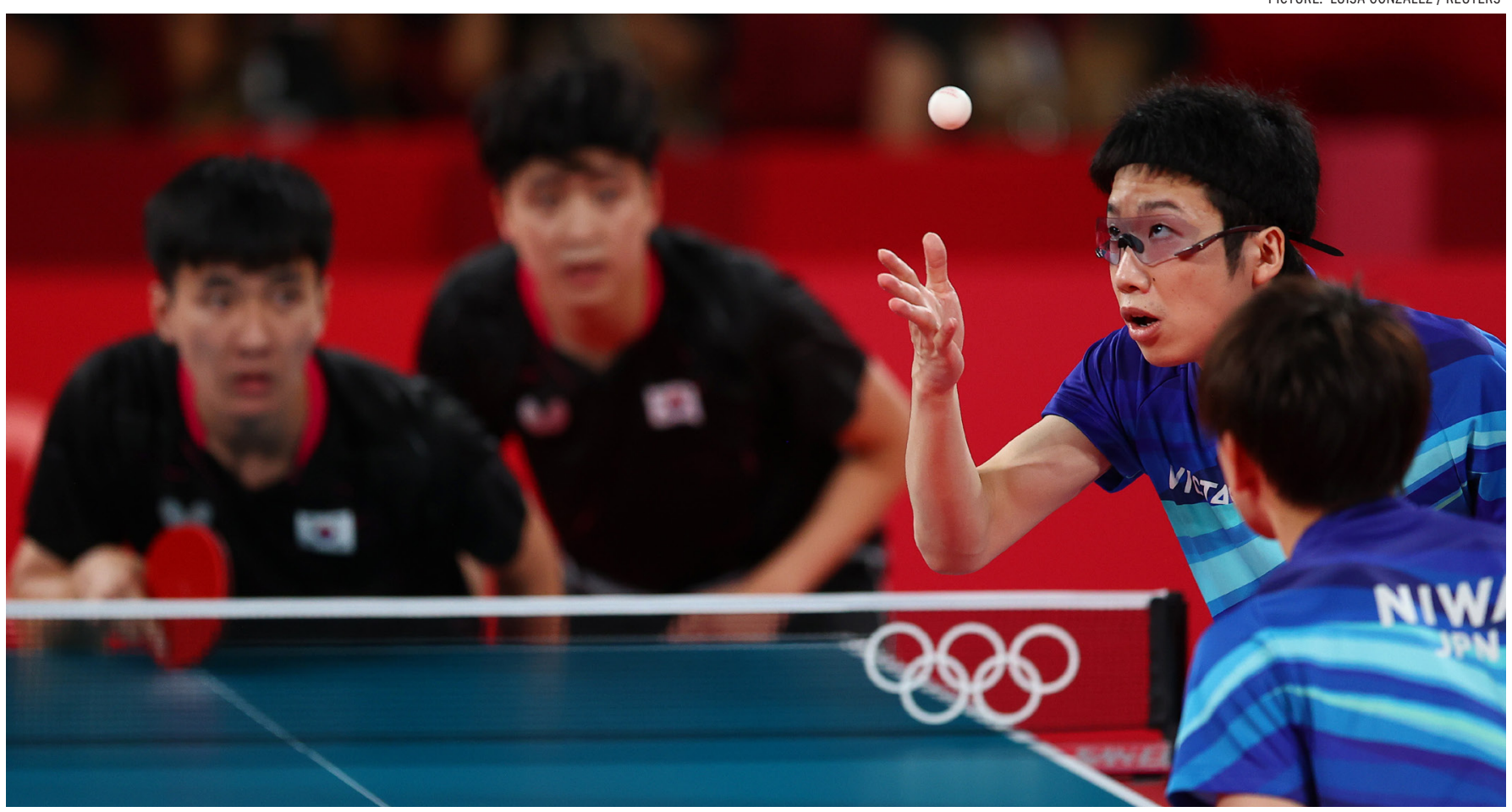

Japan and South Korea went head-to-head at table tennis for Olympic bronze (6 August 2021) but they will need to cooperate at the diplomatic table.

\title{
A new logic of cooperation for Japan-South Korea relations
}

\author{
LAUREN RICHARDSON
}

$\mathbf{T}$ HE Japan-South Korea relationship has been in crisis for the past two years. 2019 was widely cited as the lowest ebb in bilateral relations since the countries established and normalised diplomatic ties in 1965.

How did they end up back at square one?

The logical underpinnings of the 1965 normalisation process-anticommunist sentiment, US Cold War strategic objectives, South Korean authoritarianism and Japanese economic interests-were institutionalised in the form of a treaty and evolved as guiding principles for bilateral cooperation. Over time this logic for cooperation has eroded, and the bilateral relationship has deteriorated accordingly.

Nevertheless, in Tokyo, the 1965 treaty remains at the forefront of foreign policy towards Seoul and is the primary institutional framework for dealing with mutual 'history problems.' In Seoul the treaty has been delegitimised over recent decades, particularly within progressive circles and increasingly conservative ones too.

This process of delegitimisation has been driven by the rise of victim redress movements and the domestic lawsuits that are integral to their strategy. These lawsuits have challenged the legal foundations of the 1965 treaty, specifically its clause pertaining to compensation for colonial victims. The judicial efforts of Korean wartime labourers came to a head in 2019 when a South Korean court ruling on compensation essentially drove a dagger through the 1965 agreement.

The delegitimisation of the treaty in South Korea explains, in part, why the United States-the driving force behind the normalisation process and 
the architect of the logic undergirding it-has lost significant leverage over the Seoul-Tokyo relationship.

The structural context of the diplomatic crisis that Japan and South Korea face today can therefore be characterised as the crumbling of the 1965 normalisation regime. How can this dilemma be navigated by the two countries' leaders?

Groupthink on Japan-South Korea relations remains trapped in the 1965 logic that the two countries, both allies of the United States, should get along for security reasons. This view has worn thin in Tokyo and Seoul. While it makes sense in theory, it discounts the reality that both governments weigh their respective positions on history problems above the potential benefits of enhancing trilateral security cooperation. Tokyo even prioritises the abduction issue over the matter of denuclearisation in its foreign policy towards North Korea.

Japanese officials will never entertain the idea of amending the 1965 treaty to reflect the changed political realities of the bilateral relationship. This was an approach they took vis-a-vis the United States in 1960, when they amended their security treaty to rectify significant points of contention. Tokyo has instead pinned the blame for the deterioration of the relationship with South Korea on President Moon Jaein's government and is hedging its bets for an improved bilateral relationship with Moon's successor.

This interpretation of the relationship overlooks the fact that the South Korean judiciary has been steadily chipping away at the normalisation treaty since 2011, when the Constitutional Court in Seoul delivered a landmark judgement on the 'comfort women' issue. The court ruled it was unconstitutional of the South Korean government to make no tangible effort to procure compensation from Tokyo on behalf of the former 'comfort women.' In other words, the judiciary ordered South Korean officials to dispute the 1965 settlement with Tokyo. Notably, this ruling was delivered under a conservative South Korean government, six years before President Moon came to power.

W HAT the Tokyo-Seoul relationship requires is a pair of leaders who can establish a 21st century logic for cooperation, one that is not entrenched in the 1965 Cold War regional order. The foundation exists for this to occur. Both governments are pursuing a range of common objectives with bilateral and trilateral potential. They are both developing hydrogen energy links and pursuing security cooperation with Australia, seeking to maintain regional stability in the midst of intensifying China-US rivalry, trying to diversify their supply chains away from China, and grappling with an unrelenting pandemic that has brought devastation to Southeast Asia-a region in which both are increasingly invested.

Tokyo and Seoul may choose to forego the synergistic effects of coordinating their policies and continue pursuing these common objectives in parallel. This will become increasingly problematic for their mutual partners, however, given that Tokyo and Seoul will continue to be seated at the same multilateral diplomatic tables and, in the (increasingly probable) danger of a regional conflict, will be engaged on the same side. It is therefore in the national interest of both countries to seek to overcome their bilateral problems.

In addition to establishing a new logic for cooperation, there needs to be a pragmatic acceptance by leaders in both countries that their mutual 'history problems' will always occupy a place in the bilateral relationship. And it should be anticipated that victim lawsuits on the South Korean side will potentially continue for a few more years. Given these victims were not consulted in the normalisation process, it is only natural that they spend their final years pursuing justice on their terms. This reality doesn't have to unravel the relationship-it is something that needs to be managed. The institution of diplomacy exists for this purpose.

Past Japanese and South Korean leaders have typically pledged to adopt a forward-looking approach to bilateral relations but have too often reneged on this commitment when 'history problems' have reared their head. Yet the resurgence of such problems shouldn't come as a surprise. It's not as though the colonial past was wiped out from South Korean memory and consciousness when the authoritarian Park Chung-hee government signed the normalisation treaty with Japan.

Tokyo and Seoul need to establish some diplomatic mechanisms to relieve the ongoing anguish of the few surviving Korean colonial victims when their claims for justice and compensation resurface. This wouldn't necessarily have to entail overturning or even undermining the 1965 treaty. It should involve creative diplomacy that is designed to deal with the growing political empowerment of colonial victims in South Korea and their continued leverage over the diplomatic relationship. EAFQ

Lauren Richardson is a Lecturer in the Department of International Relations, The Australian National University. 


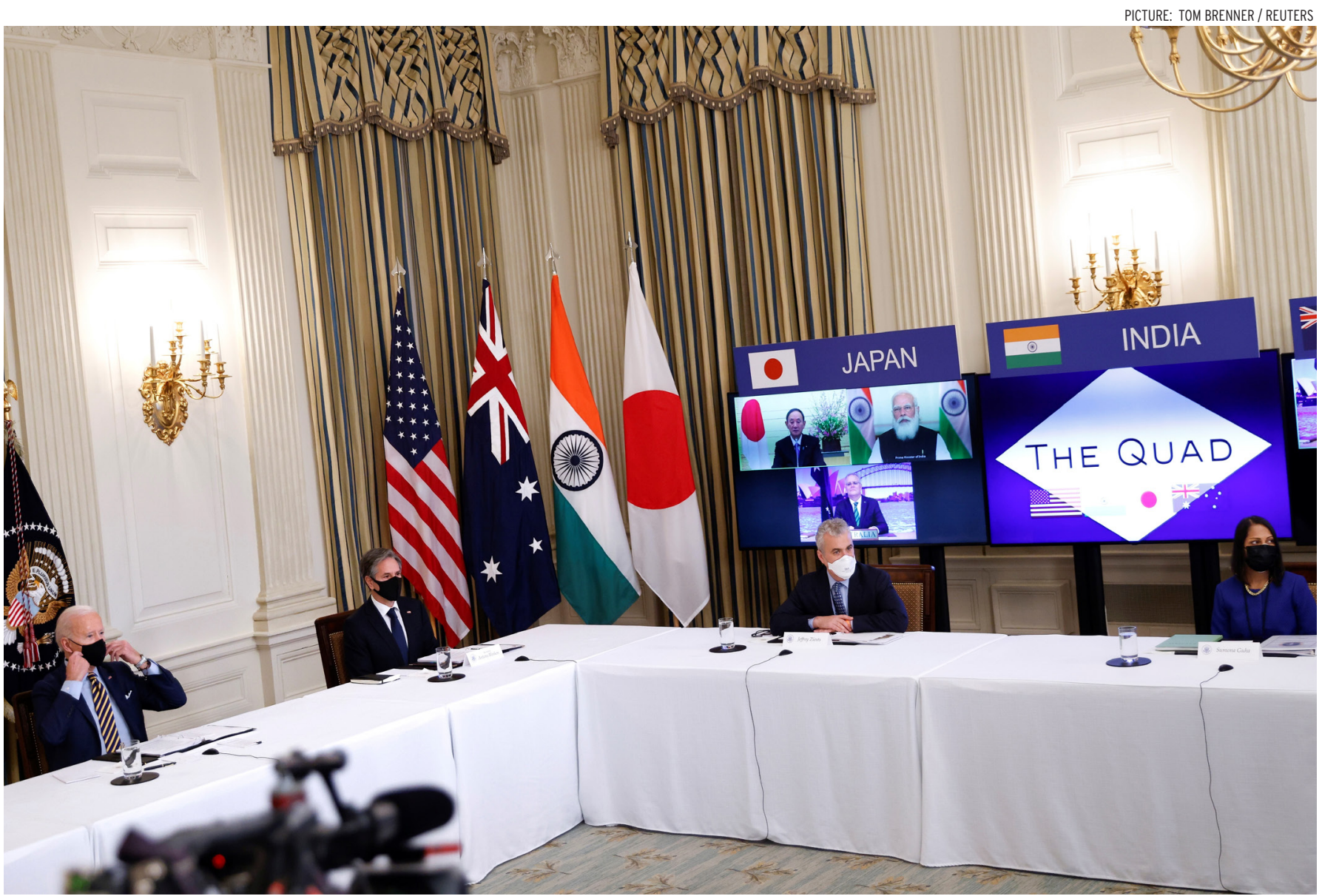

Members of the Quad are shown meeting for the first time at head of government level (March 2021).

\section{The Indo-Pacific construct and the reality of Chinese power}

kerareranum

1 S A testament to how appealing idea of there being a coherent territory called the Indo-Pacific has been around for some years. It surfaced in the first Abe premiership in 2007 when he spoke at the Indian parliament about the notion of 'the confluence of two seas.' Other leaders in the Asia too had alluded to the idea of a greater definition and concreteness to multilateral cooperation in the region. Transplanted by the US Naval War College at a conference in Sydney in 2011, the more recent, clearer idea of the Indo-Pacific began to take its roots in the Australian search for regional security under prime ministers Julia Gillard and Tony Abbott, when Peter Varghese was the head of Australia's Department of Foreign Affairs and Trade.
In his Charteris Lecture in 2013, Varghese marked dissatisfaction with the nebulous concept of Asia. 'We need to expand our concept of Asia. A new Indo-Pacific strategic arc is beginning to emerge, extending from India through Northeast Asia to Southeast Asia and the Pacific, including the sea lines of communication on which the region depends' 
It is no coincidence that the tighter and more urgent formation of this idea has happened at precisely the same time as China has risen to be economically and geopolitically so prominent. That alerts one to the insight that there would be no IndoPacific were there no China. The bottom line is that the intellectual and diplomatic investment in the whole idea of the Indo-Pacific has been driven principally by the desire to find a viable counterbalance to China and the ways in which-as an economic and geopolitical actor-it was gaining increasing power and influence across the region.

The question is whether the investment has, and ever will be, worth it. The sheer complexity of the different partners embraced, the issue of how limited are the resources available to make the Indo-Pacific meaningful, and the fact that it is faced by a Chinese counter narrative which is being promoted more forcefully and urgently all pose formidable problems for the concept. It is likely that, in the end, the only real strength the idea will have is to create slightly better dialogue in a region where the record of this has been poor. More negatively, it might simply symbolise worry and opposition to Chinese influence in the region. Whether it will practically achieve anything beyond minimal containment is unlikely.

To start with the positives, at least we can say that in 2021, Varghese's idea has more tangibility than it did back in 2013. For a start, more people are speaking about the Indo-Pacific, inside and outside the region. The United States, Europe and countries in the region have invested publicly in the idea, in terms of diplomatic commitment and actual resources. The Quadrilateral Security Dialogue (Quad)-consisting of Australia, the United States, Japan and Indiainitiated in 2007 by Japan, was resuscitated in 2017. In March 2021, for the first time ever, its meeting was held at the head of government level, forming part of the new Biden administration's move to restore and recommit the United States to multilateralism after the chaotic Trump years.

The Quad is only the most striking form of regional arrangement and focuses on making the idea of the Indo-Pacific real. Others are also

PICTURE: US NAVY PHOTO / SEAMAN JOSHUA L. LEONARD / ABACAPRESS / REUTERS

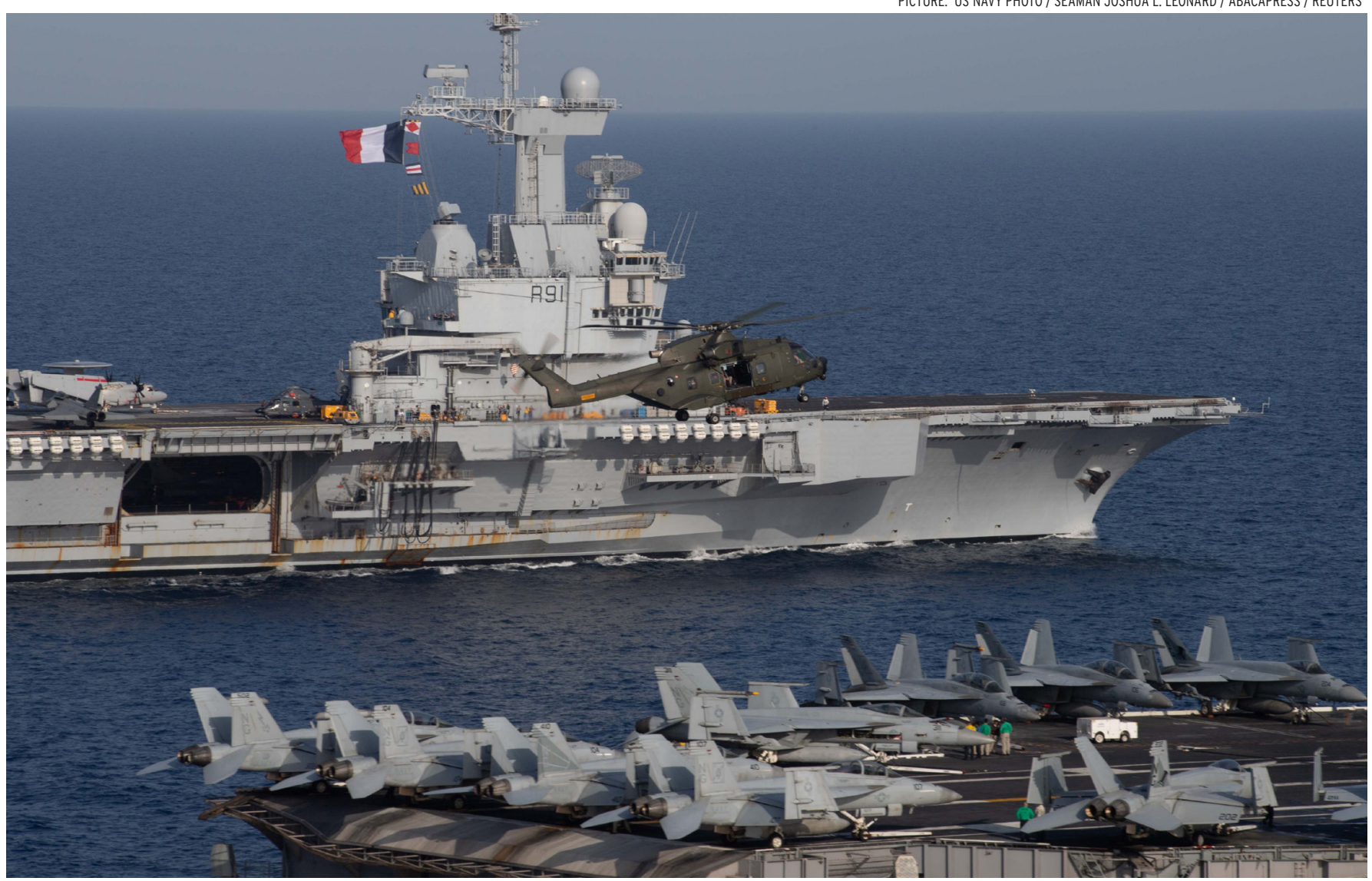

The French Marine Nationale aircraft carrier FS Charles De Gaulle and the US Navy aircraft carrier USS John C. Stennis underway in the Red Sea (April 2019). 
investing in the notion. The United Kingdom's March 2021 'Integrated Review' of foreign and security policy also talked at length about the region. The Indo-Pacific, it declared, '... matters to the UK: it is critical to our economy, our security and our global ambition to support open societies ... In the decades to come it will be the crucible for many of the most pressing global challenges-from climate and biodiversity to maritime security and geopolitical competition linked to rules and norms'.

In a move to ensure that this was more than just reassuring rhetoric, the newly deployed Queen Elizabeth aircraft carrier was sent to the South China Sea region in July, drawing the ire of China. In March, too, France sent its own warships to the region before undertaking exercises with the United States.

E VEN as this effort has been undertaken to build some kind of viability to the Indo-Pacific idea China has not been passive. It has been strengthening its own regional narratives. The Belt and Road Initiative (BRI), which originated about the same time as Varghese's talk, has been at the centre of this. And since 2013, despite all the effort by the Quad and others, the BRI has been a more compelling international vision than the Indo-Pacific. This is despite the fact that criticisms of BRI have come thick and fast. It has been accused of being a debt trap, riddled by poor governance and environmental standards, and has been associated with conditions that demand the employment of Chinese imported labour. Perhaps most pointed of all, are assertations that the project is designed to carry and promote Chinese geopolitical ambitions across the region into the wider world.

But the brute fact is that the BRI is being talked about, engaged with, and figuring in people's strategic thinking. To apply Oscar Wilde's famous saying in a novel context, if the one thing worse than being talked about is not being talked about, then the BRI has proved a roaring success.

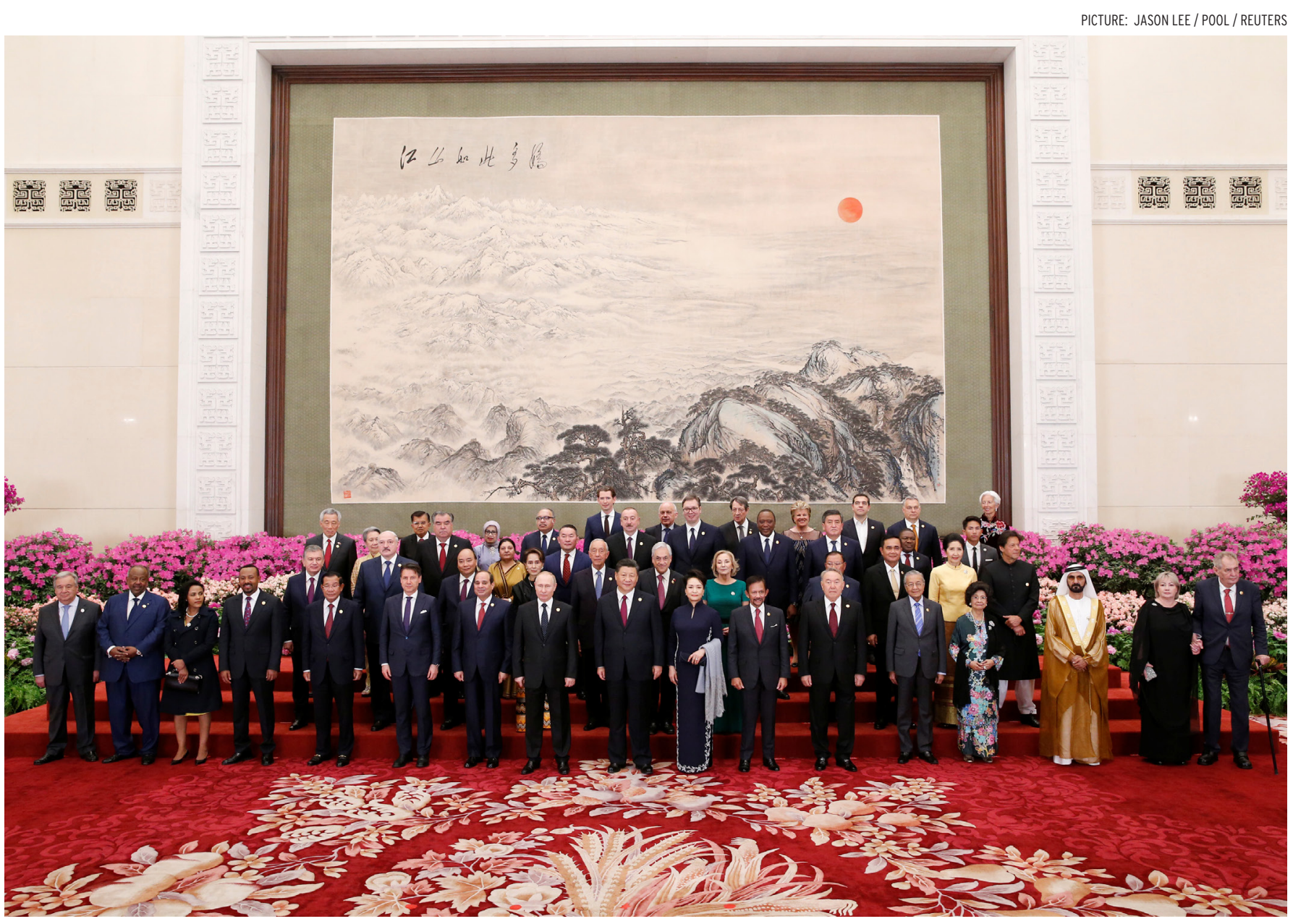

President Xi Jinping and other leaders gather before a welcoming banquet for the Belt and Road Forum at the Great Hall of the People in Beijing (April 2019). 


\section{The framing of the Indo-}

\section{Pacific here in terms}

\section{almost wholly figuring}

\section{China-albeit expressed}

indirectly-is telling

The Indo-Pacific might be receiving some attention. The BRI is receiving vast waves of it. That shows that it has captured the imagination of those who were already willing to work more closely with China. Pakistan, for instance, has signed up. So too, more surprisingly, has Russia. The biannual summits on the BRI held in China may not have attracted many key European or North American leaders, but central Asian, African and Latin American leaders have all taken part. They can dislike and disagree with BRI. But the one thing they cannot do is ignore it.

The amorphousness of the BRI idea, far from being a weakness, is its great strength. Representatives of 150 countries came to the 2019 summit. The slimmed down, mostly online, June 2021 summit had around 29 senior representatives from regional countries. Over this time, to add to its armament, the BRI has morphed partly into a 'health and wellbeing BRI' to respond to the COVID-19 crisis. The current Chinese leadership never passes up opportunities to present themselves in a good light, even in the most hostile of terrains. It is likely there will be many other versions of the BRI going into the future. Like all good stories, it can be told many times, in slightly different ways, and still remain the same broad story.

America, Europe and others (including, it is clear, Australia) would dearly love something other than the BRI. The question is can there be such viable alternatives-or, for that matter, stronger counterbalancing motivations which are compelling enough and as equally appealing that they stand a chance of restraining and focusing away from those of China? What attempts there have been so far have proved tepid and unpromising, at least in terms of grabbing the imagination. At the June 2021 G7 meeting in the United Kingdom, there was talk of a 'Build Back Better' program and of deploying large amounts of investment into infrastructure and construction.

The Indo-Pacific did merit one specific mention in the G7's final 27-page communique, where it was stated that the United States, the United Kingdom, Japan, France, Germany, Italy and Canada 'reiterate the importance of maintaining a free and open Indo-Pacific, which is inclusive and based on the rule of law. We underscore the importance of peace and stability across the Taiwan Strait, and encourage the peaceful resolution of cross-Strait issues. We remain seriously concerned about the situation in the East and South China Seas and strongly oppose any unilateral attempts to change the status quo and increase tensions.'

The framing of the Indo-Pacific here in terms almost wholly figuring China-albeit expressed indirectly-is telling. It is clearly an idea that largely exists in order to stand against another one, rather than something that might have any valid purpose as a standalone. It almost serves as a proxy for China, which itself only merited one other explicit mention in the document. More space was allocated to Myanmar and Iraq. Nor was there much faith that the G7 would be able to compete with the resources of the BRI. The aspiration was a worthy one. But huge questions remain about what might come from all this talk.

C AN the Indo-Pacific be, as the G7 communique states, a space where rules-based liberal norms prevail over the autocratic, more selfinterested habits the Chinese have been accused of? Even if one assumes that the commitment of the United States and its allies to this space as a real counterbalance to Chinese hegemony is solid and long term, there are a number of very tricky questions which mean scepticism about the concept remains valid.

Most importantly, there is the issue of cohesion. The BRI is united by at least one solid commonalityChinese interests. The Indo-Pacific is a far messier idea and doesn't originate from one source. Asian multilateralism, if one focuses narrowly on that, has a scratchy track record. Sovereignty was hard-won in this region after varying experiences of colonisation and nation building in the early 20 th century. One could argue that the Westphalian notion

The idea of a 'softer'

Indo-Pacific which is a space for better and deeper communication

and clears away some

of the blockages that exist at the moment is probably more viable and necessary 


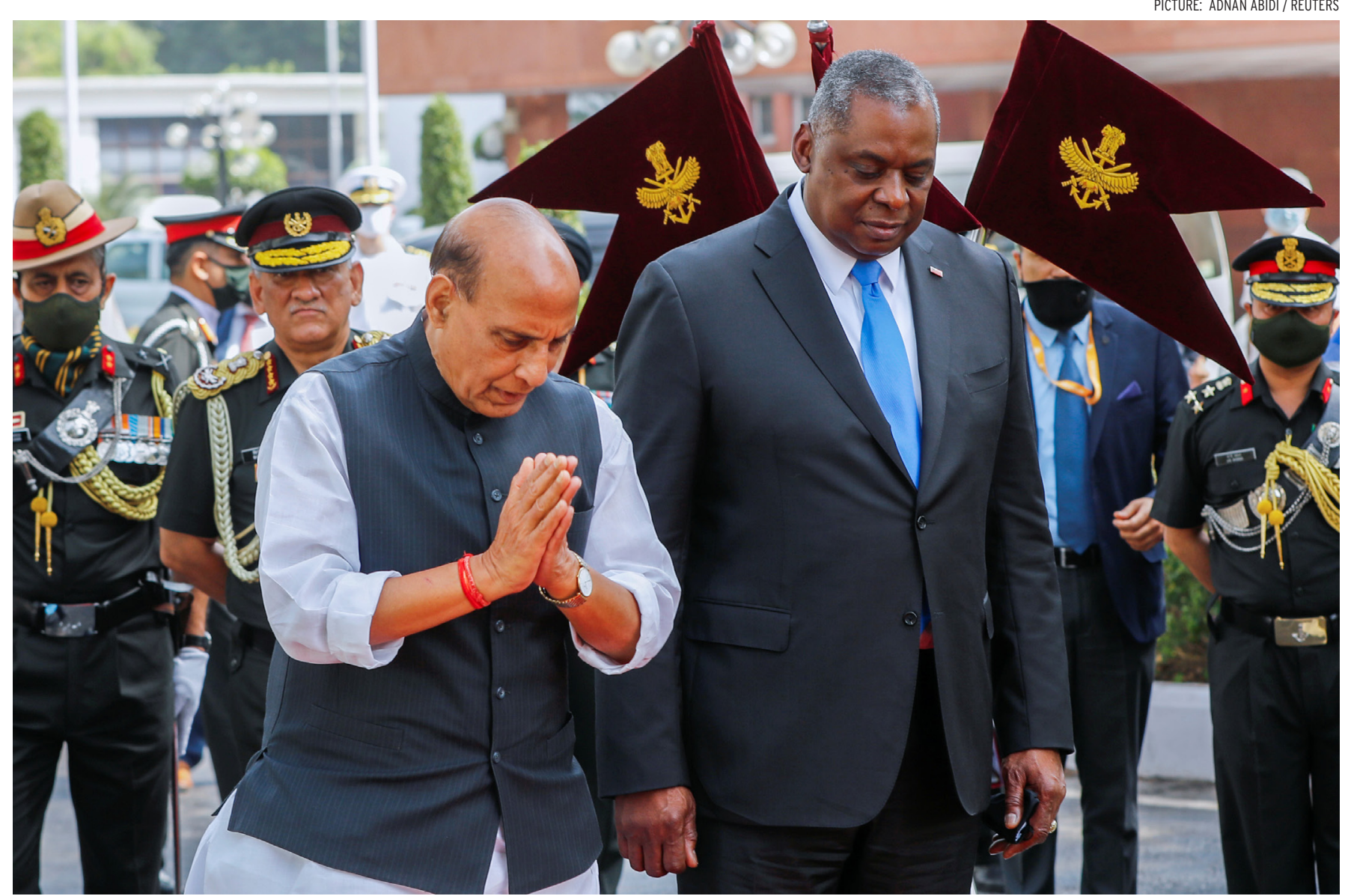

India's Defence Minister Rajnath Singh and US Secretary of Defense Lloyd Austin greet the media during a ceremonial reception in New Delhi (March 2021).

of statehood has been one of the most successful Western exports to this region. In this context, everyone jealously preserves their own interests. There is little commonality. It is deeply ironic that the one potential source of this is now fear of China. That is hardly a positive idea on which to build solid multilateral cooperation.

\section{NDIA, a key player if the idea were ever to flourish, exemplifies} this, and is one of the key fault lines in the whole concept of the IndoPacific. If India doesn't fit into this notion, then it is hard to see how it can work. But India is a tricky player to fit into any neat multilateral framework. Australia's hopes that it might-as a market, source of overseas students and security partner-be a counterbalance to China have proved salutary over the past decade. The assumption that India would be a more compliant partner because it is a democracy has proved misplaced. Its economy is attractive, but it remains only a third of the size of China's. Before COVID-19, growth was 7 per cent or more, higher than in China. Post-pandemic, things look far less optimistic.

Despite being a democracy, Prime Minister Narendra Modi's style of government is muscular nationalism and his clamp downs on free speech and legal action have proved increasingly problematic. As one commentator acidly noted in Australia in 2015, 'whenever India joins a trade agreement, it degrades the quality of the agreement.' It effectively scuppered the Doha Round of talks in the WTO that year, it walked away from RCEP in 2019, it lacks anything like China's infrastructure and has proved a market every bit as complex and hard to enter as China's.

The geopolitics make this problem even more severe. India is a highly autonomous actor. Attempts by former US president George W Bush in the 2000s to draw closer to it proved frustrating. India might not have an optimal relationship with China-with constant clashes over the contested border between the two from 2015-but Modi's desire to be closer to $\mathrm{Xi}$ Jinping creates an unsettling ambiguity. 
Nor is it in India's interests, occupying the front line, to antagonise and create needless tension with its huge and powerful neighbour. It certainly does not want to be used as a proxy diplomatic weapon because it, rather than others, would take the brunt of any tension with China. India enjoys amicable relations with Russia and has procured military kit from Russian President Vladimir Putin, despite US anger. It has its own clear strategic interests which do not align with those in the United States, Europe or Australia. To see India therefore as an easy substitute for China is a daydream.

$\mathbf{E}$ LSEWHERE in the region, to a lesser degree, there are other countries that may have issues with China. But the attitudes in these countries are driven far less by ideology and notional values and much more by pragmatism and self-interest. Malaysia, Indonesia, the Philippines and Vietnam all face very different issues and approach their great neighbour in different ways. What would unite them is a clear desire to avoid needless turbulence provoked by those distant from the region.

An Indo-Pacific with any real chance of enduring will need to focus on generating a viable and pragmatic framework for cooperation, something that can work within the very different political and security worries that exist across the region. It would also have to be a framework that would at least persuade everyone it could protect them and serve their interests. That includes China. It is hard to see India, let alone any of the other players, working with an idea that antagonises China and creates problems for them. They are sitting in the front line if there are problems - the United States and others are not.

The idea of a 'softer' Indo-Pacific which is a space for better and deeper communication and clears away some of the blockages that exist at the moment is probably more viable and necessary. For this to happen, it would make sense for partners in the region to take the lead in this, rather than allowing it to be shaped by the very different priorities of the United States or others. Otherwise we hit the defence of sovereignty issue quite quickly.

But as a more solid security alliance, with the kind of appeal to the imagination that the BRI has, the Indo-Pacific is fatally flawed. At most, it risks non-Asian powers trying to impose themselves among a set of relationships and a reality where they simply no longer have the economic, diplomatic and security resources to have the impact they wish. As that sort of idea, the Indo-Pacific is much like the way de Gaulle described Brazil: 'a place of the future' caustically following this up with, 'and always will be'. EAFO

Kerry Brown is Professor of Chinese Studies and Director of the Lau China Institute, King's College London, and Associate Fellow with the Asia Pacific Programme at Chatham House.

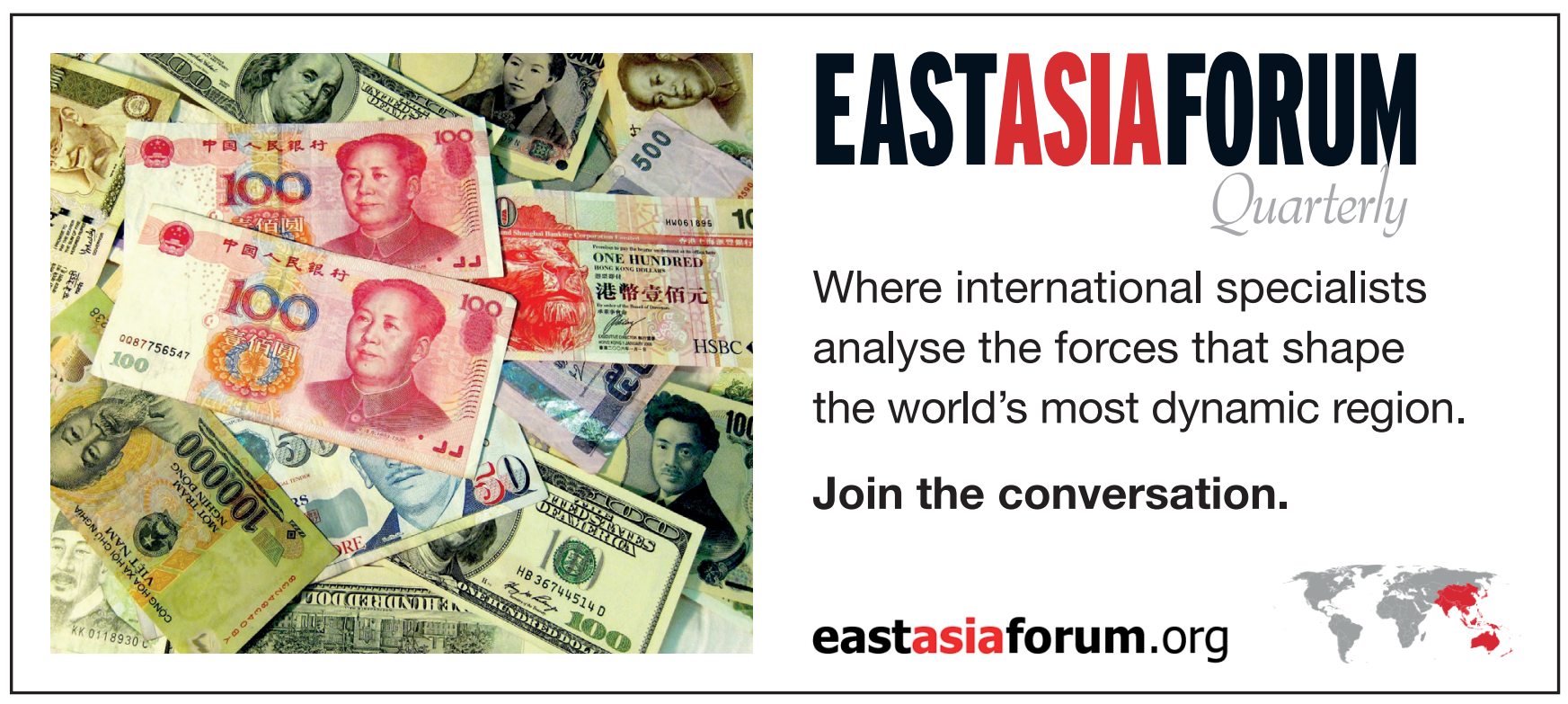




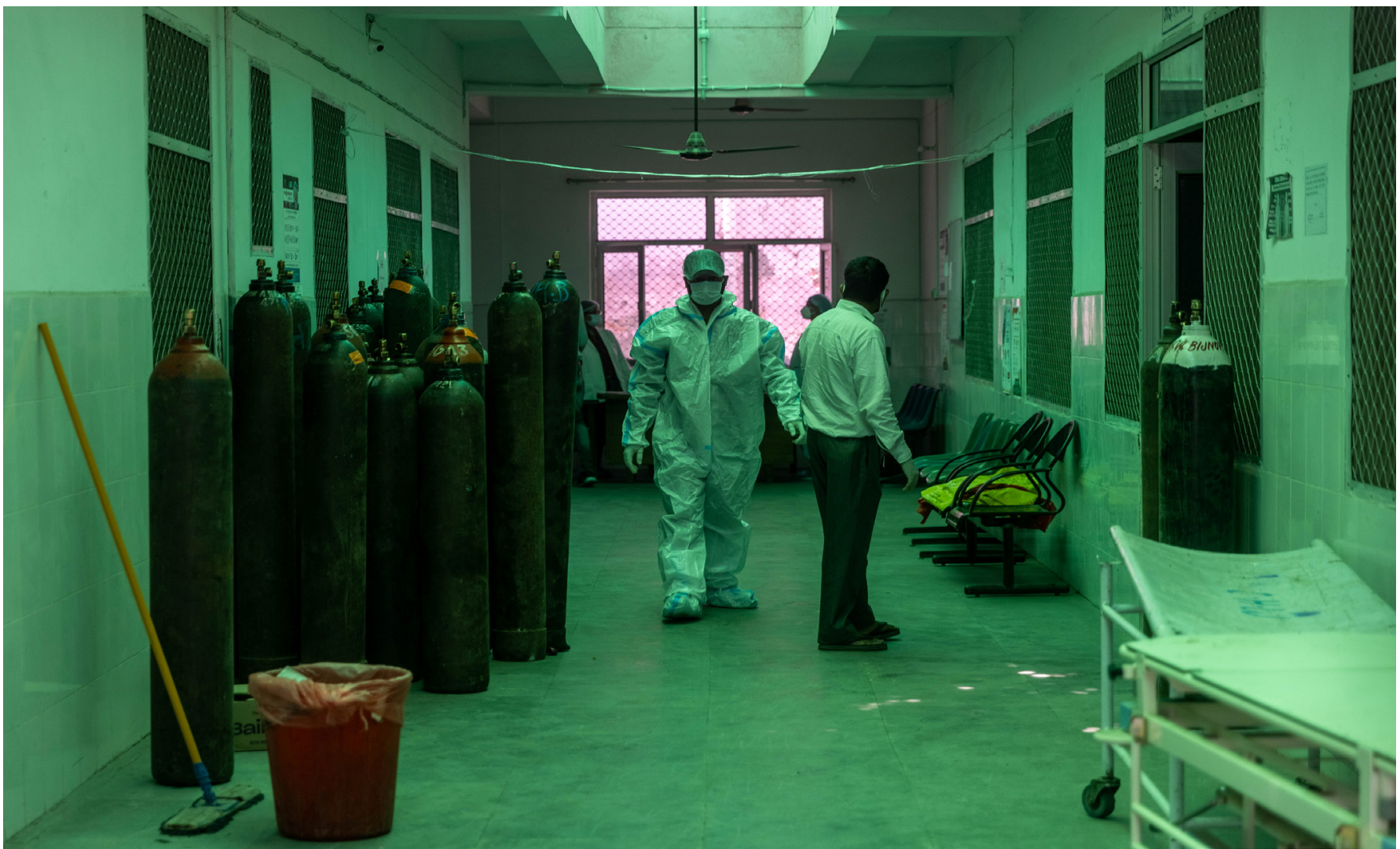

A healthcare worker walks past oxygen cylinders outside a government-run intensive care unit in the Bijnor district, Uttar Pradesh (May 2021).

\section{COVID-19 exposes India's fragile federalism}

NIRANJAN SAHOO AND AMBAR

KUMAR GHOSH

\section{- MERGENCY and disaster \\ c management demands a} command-and-control approach. So when COVID-19 swept the world in early 2020, most observers projected a difficult time ahead for countries with a federal system. Given the decentralised pathways that most federal countries follow, there were serious concerns about how diffused systems could handle a rapidly spreading viral pandemic. Such concerns became more glaring as federal countries such as the United States, Brazil and Canada found themselves at the receiving end of the pandemic.

India surprisingly turned out to be an outlier in this initial wave. While many Indian states were challenged by a rapid surge in infections over the first few months, especially in
August, India gained an upper hand over COVID-19 over the next few months. Not only was India able to prevent high fatalities-1.7 per cent against the global average of 3.04 per cent in 2020-the country was able to manufacture critical medical materials such as personal protective equipment and essential drugs in record time and help supply them all over the world.

The country was at sea when a 
more infectious second wave hit India's most populous states-like Uttar Pradesh, Maharashtra, Gujarat and Karnataka-in early March 2021. From being a global poster boy in 2020, India's handling of the pandemic became a major embarrassment. The federal government, affected states and their healthcare institutions were completely overwhelmed while hapless citizens struggled for hospital beds, oxygen cylinders and essential medicines. It even created a temporary situation of state collapse.

NDIA'S success in handling the first wave showed that the system can work. The Indian constitution dictates that the handling of health crises, including pandemics, largely falls within the domain of states. Yet given the pan-India nature of the threat posed by COVID-19, the central government, with its huge leverage over resources and expertise, assumed the lead and took many key decisions unliterally. It derived these powers by invoking the Disaster Management Act 2005, which made the Ministry of Home Affairs the lead in a national response.

Still, these powers were not always used effectively. The Ministry issued compulsory guidelines and instructions to the states on matters that ideally should have remained in the states' jurisdictions. In numerous instances, the central government's blanket decisions on lockdowns and containment zoning were made without adequate knowledge of the situation on the ground. For example, the states were not allowed to purchase medical kits on their own without federal permission.

Given the nature of the pandemic, the states had little choice but to grudgingly accept temporary loss of power and autonomy and they largely cooperated with the central government. The upside was that while the government initially centralised pandemic management and assumed many functions of states hindering federal spirit, it rolled out timely and critical measures. This included scaling up efforts to plan the production of vaccines domestically, setting standards and guidelines, and ensuring inter-state coordination. After an initial phase of hyper-centralisation, the national government, realising the need for a decentralised approach for combating the pandemic, conceded space to the states in many areas of decisionmaking, like lockdown measures and containment zoning, which required a localised approach. Proactive federal leadership-though highly centralised initially-was eventually compelled towards relatively healthy cooperation with states, which was essential for

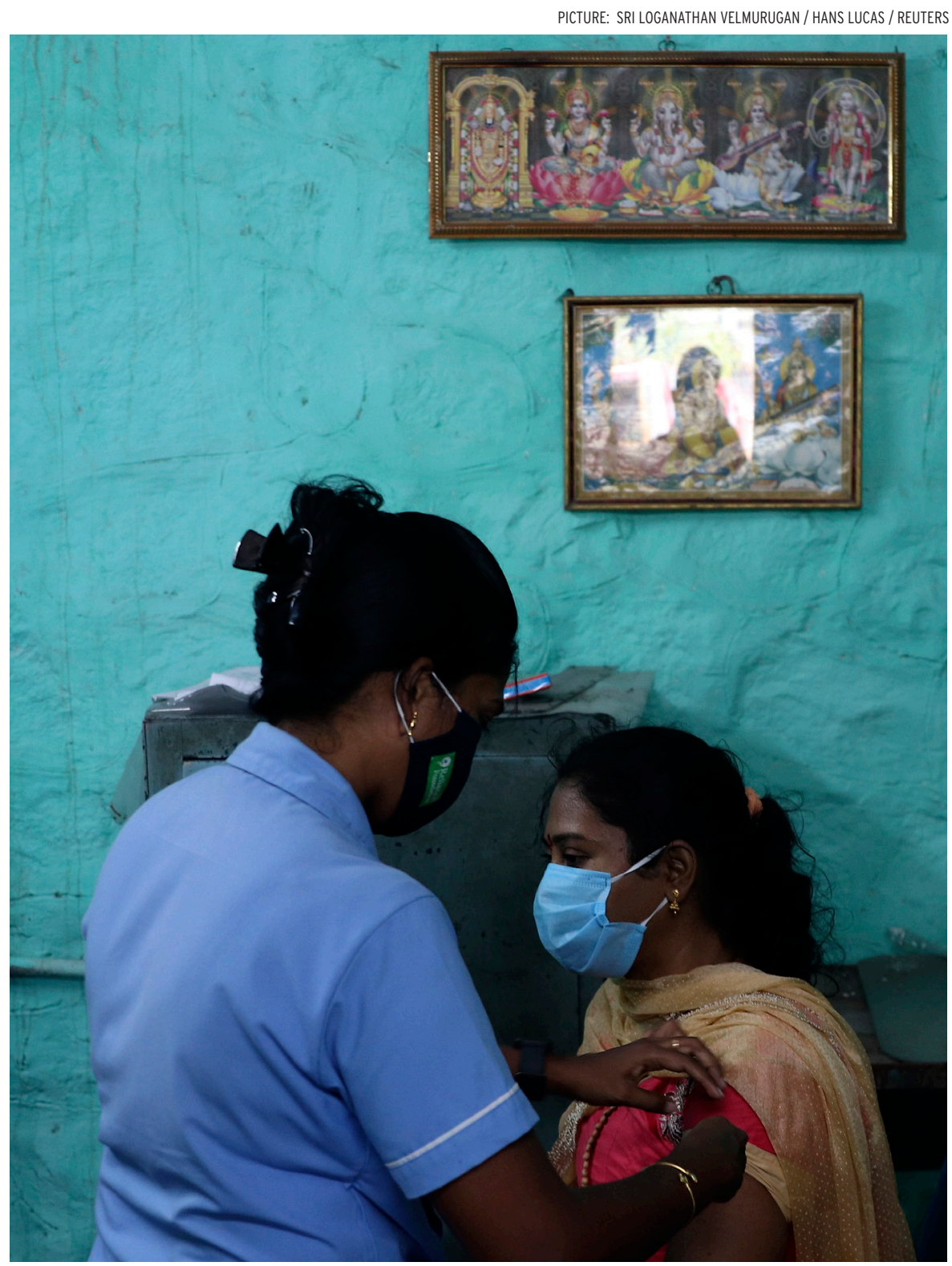

A woman receives the Covishield COVID-19 vaccine at a clinic run on school premises (Chennai, May 2021). 
getting a grip on the first wave.

While the first wave of the pandemic was handled swiftly and decisively through overt centralisation followed by gradual decentralisation, the opposite was true in the case of the disastrous second wave. Despite a series of early warnings and alerts in February 2021 from epidemiologists and from its own scientific advisory body about the spread of a new and deadlier variant, the central government and its responsible agencies chose to ignore them.

On the contrary, India's health minister announced that India was witnessing the 'dead end' of the pandemic in early March. Not long ago, Prime Minister Narendra Modi while addressing the World Economic Forum claimed that India was among few countries to have successfully controlled the pandemic. To compound the problem, and despite credible warnings from experts, authorities allowed the major Hindu religious festival, Kumbh Mela, to proceed, while the central leadership threw itself into election campaigns in five states, holding mass rallies without

\section{What was more}

surprising was that

instead of adopting a

swift and possibly more

centralised response

the central government

unilaterally decentralised

the pandemic response pandemic-related restrictions.

The central government began taking note when many states started experiencing rapid surges in infections and health systems were overwhelmed, triggering panic and public outcry including among the core support base of the ruling party. As the public outcry grew louder about the lackadaisical approach it took to the more virulent second wave, the central government opportunistically passed the blame onto the states-now arguing that health is a state issue. At the same time, it accused oppositionruled states of politicising pandemic management.

What was more surprising was that instead of adopting a swift and possibly more centralised response the central government unilaterally decentralised the pandemic response. It failed to issue required central guidelines or alerts to the states and local bodies and refrained from ordering a national lockdown-as it had promptly done during the early stage of first wave-while the infections began spreading like wildfires. Thus, the pendulum swung from outright centralisation to unilateral decentralisation.

The decentralisation logic became more visible in the case of India's COVID-19 vaccination policy. As the country faced acute vaccine shortages, many state governments called for autonomy to procure the vaccines from international markets. The central government, which from the beginning had assumed sole responsibility of procuring and distributing vaccines, promptly acceded to these demands, even though this was considered impractical given the stiff global competition for vaccines. Many states that went ahead with tenders found no prospective bidders. This, along with differential pricing of vaccines, created a chaotic situation and an ugly blame game between the central government and the states. In the process, India lost precious time in its fight against the pandemic and the vaccination drive suffered a severe blow. It finally required the intervention of the Supreme Court to end the deadlock. While the central government took back the responsibility on vaccination policy, the avoidable impasse damaged the trust and cooperation that had been built between the two principal stakeholders of federalism during the first wave.

M ANY opposition-ruled states cannot escape the blame for making impractical and politically motivated demands on vaccine procurement and for politicising the central government's vacillation on vaccination to hide their own ineptitude. But the principal author of the disastrous second wave is the central government. While triumphalism, complacency, politicobureaucratic lethargy, delayed decisions and an obsessive fixation with assembly polls accelerated the second wave and caused unparalleled devastation, what was missing was federal leadership. A lethargic central governmentwhich was less visible and mostly functioning through directives and policy announcements-struggled to organise disarrayed states and health institutions to mobilise a unified response during a more infectious second wave. The central government's authority failed as chaos and lawlessness ensued on the streets, with states fighting over oxygen and essential medicines until the urgent intervention of the judiciary.

This was not the case in first wave, when the federal government showed 


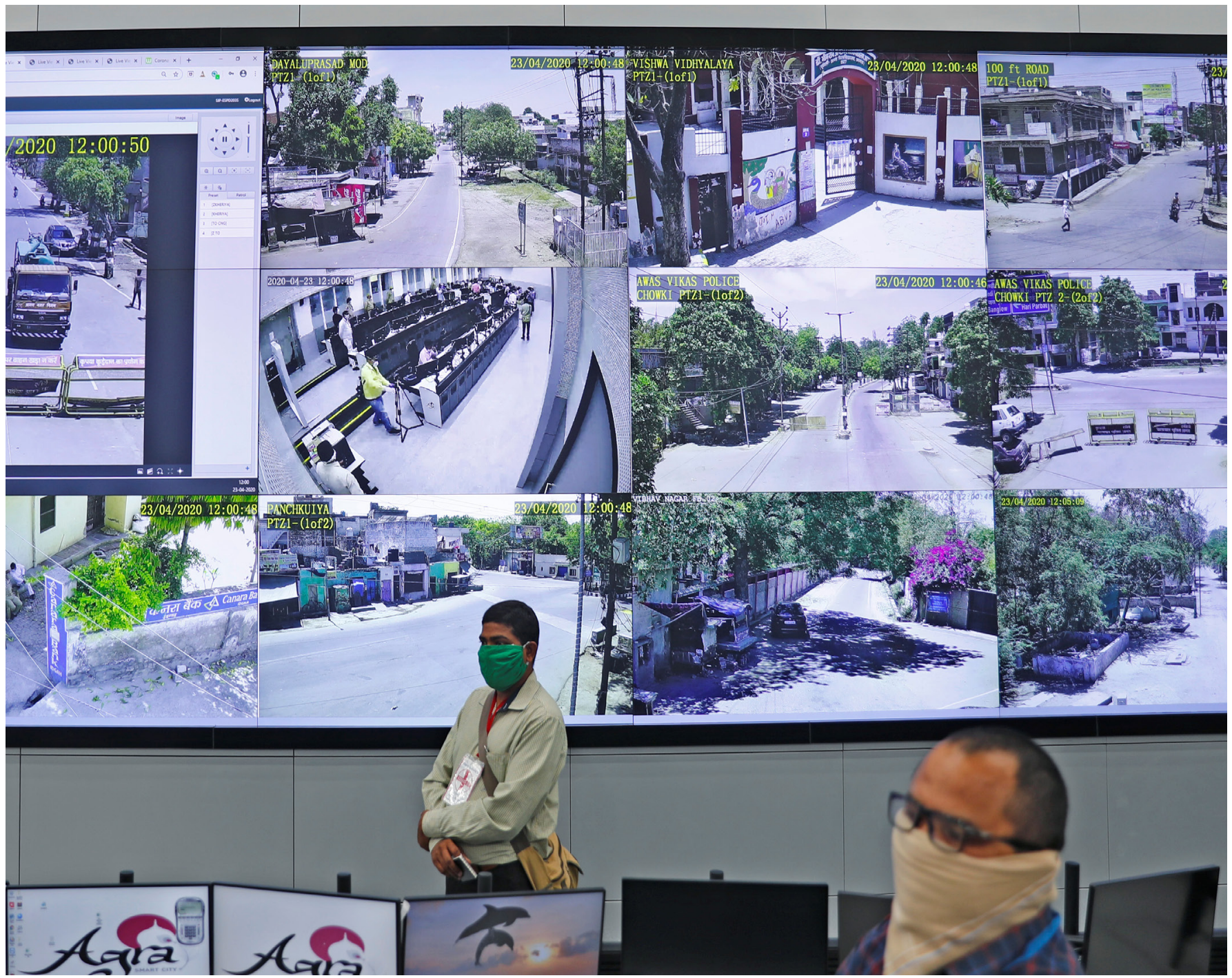

Officials work inside a control room to monitor the movement of people during India's initial nationwide lockdown to slow the spread of COVID-19 (Agra, Uttar Pradesh, April 2020).

the alacrity required to get the states on board for consultation, heeded experts and put up a purposeful response despite India's weak public health system and low state capacity. Effective central-state cooperationlargely steered by the federal leadership - helped India navigate the crisis with minimal fatalities. The second wave was, of course, a more infectious new variant that would overwhelm even most advanced healthcare system anywhere in the world. Yet, a more prepared federal government could have minimised the devastation and avoided the unlikely situation of state collapse as experienced during the peak of infections in April 2021, as the more effective responses in the United States, Australia, Canada and Germany suggest.

India's performance in the second wave should serve as a warning for all federal states: that the key to success in a federal system lies in effective and purposeful federal leadership that can build bridges between the states and a well-coordinated response. A point of reference here is the story of the turnaround in the United States. With some notable exceptions, US responses to the pandemic suffered heavily from vacillating federal leadership under Donald Trump. In contrast the Biden administration has demonstrated what a difference purposeful federal leadership can make. EAFQ

\section{Niranjan Sahoo and Ambar Kumar} Ghosh are Senior Fellow and Junior Fellow with the Observer Research Foundation, New Delhi. 


\section{CRISIS MANAGEMENT}

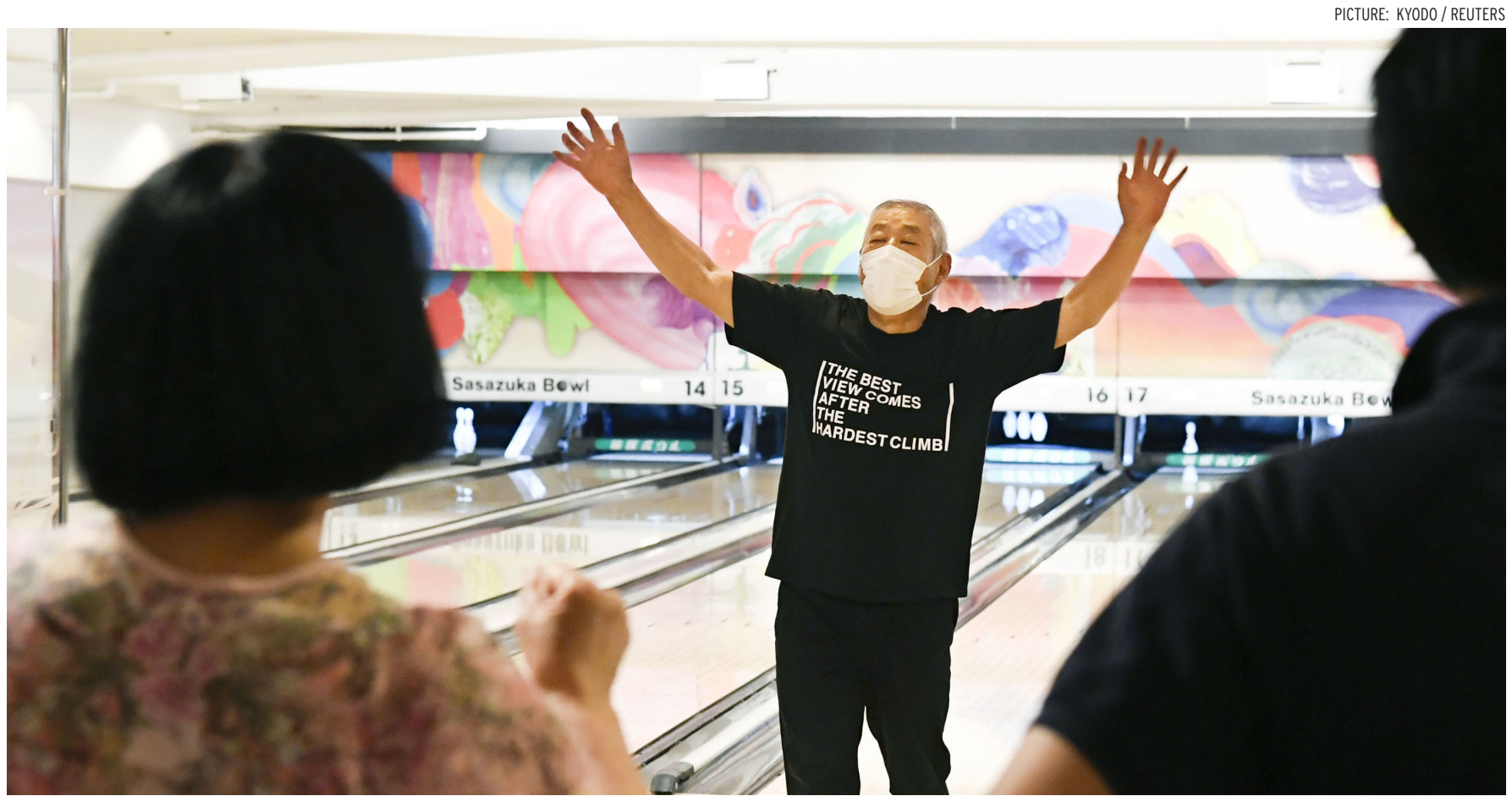

Studies indicate that strong civic and social infrastructure can enable societies to overcome collective action problems in times of crisis.

\section{The benefits of social infrastructure and civic ties in uncertain times}

Danti A A DOBCH

$\mathbf{U}$ NTIL recently, it may have been hard for the average person to grasp how deadly and damaging disasters and shocks can be. No longer. Few anywhere in the world have emerged from the past year and a half without a strong appreciation of the impact of the global COVID-19 pandemic. Along with COVID-19 taking more than 4.5 million lives and upending health systems, business revenue and global logistics, other acute and long-term shocks and stressors have affected communities around the world, including bushfires in Australia, North America and
Europe, lethal heatwaves in Oregon, and mudslides in Japan.

In Japan and elsewhere, policymakers often respond to disasters by falling back on standard responses involving physical infrastructure and megaprojects. Extreme weather events such as flooding and heatwaves are among the most common disasters, and in Japan, for example, central and regional government officials have pushed for the construction of massive concrete seawalls and tetrapods to protect coastal communities.

Japan is one among many nations that instinctively turn to such solutions when seeking to mitigate climate change and rising seas. Venice relies on Project MOSE with its inflatable floodgates to reduce flooding in La Serenissima. Boston considered a US $\$ 11$ billion seawall to try to reduce the impact of regular flooding during king tides.

Politicians and bureaucrats rely on the standard approach of building physical infrastructure in response to disasters for several reasons. First, physical infrastructure provides a visible, tangible symbol of 'doing something' for those seeking 
re-election. Second, cost benefit analyses can more easily estimate the outcome of a physical structure than less tangible projects. Third, the construction industry has a strong and successful history of successful lobbying for new work. Fourth, alternative, non-physical infrastructure approaches such as citizen research, community budgeting, and civic engagement come with longer time horizons.

Two often submerged types of infrastructure-civic infrastructure and social infrastructure-play critical roles in crisis management. Civic infrastructure is made up of bonding, bridging and linking social ties. Bonding ties are connections between similar friends and family. Bridging ties are connections to people different in some way, through institutions like schools, workplaces and places of worship. Linking social ties are vertical ties to those with power and authority.

Social infrastructure comprises the libraries, parks, nature walks, community health facilities, public schools, transportation networks and pools that help people interact and build trust and civic infrastructure. There are three critical reasons why these types of connections and infrastructure are important-perhaps even more important than the physical infrastructure communities fall back on to protect themselves from disasters.

First, strong civic and social infrastructure allow societies to overcome collective action problems. That is, challenges that require people to work together even though they may have their own interests to consider. For example, when the 1995 Kobe earthquake triggered massive fires across the city, some affected neighbourhoods were able to selforganise to fight the fires.
$\mathbf{E}$ VERYONE has experienced a collective action problem at the height of the COVID-19 pandemic when health authorities asked people to wear masks. While a relatively minor burden, mask wearing is most effective when almost everyone does it. When citizens trust the public experts and the efficacy of the advice they provide, it is easier for people to cooperate willingly.

Second, strong civic and social infrastructure better guarantee the provision of mutual aid and informal insurance during shocks when standard providers of assistance may be out of service or unable to assist. Our 2017 study of hundreds of evacuees from Japan's Fukushima nuclear meltdowns showed that people with stronger ties to neighbours significantly reduced their overall levels of stress and anxiety when compared with those without such networks. Similarly, tighter knit communities along the Tohoku coast were able to help the elderly and infirm reach high ground, measurably reducing mortality when compared with less tight-knit neighbourhoods.

The third reason that civic infrastructure serves as a critical component in disaster management is because of its ability to provide trusted information through bonding, bridging and linking social ties. While a random voice on the radio may have little influence on behaviour, people are much more likely to pay attention if a trusted friend or family member provides advice.

Before and during disasters, authorities try to push out a tremendous amount of information to motivate effective responses to crises. Before hurricanes and floods arrive, for example, officials want people in vulnerable areas to evacuate. Research shows that individuals with broader, more diverse networks are more likely to be evacuated from areas about to be hit by hurricanes than people with smaller, more insular ones. Trust between residents in Japan and authorities also helped reduce initial outbreaks of COVID-19 as people followed the health guidelines set down by the government.

In the United States, President Joe Biden's infrastructure investment plan recognises the failing state of much of the national physical infrastructure, and Japan's physical infrastructure also needs investment. But governmentsincluding that in Japan, which ranks among the lowest of the advanced industrial democracies in terms of its social capital-also need to invest in social infrastructure. Japan, for example, has lower rates of volunteering than most other OECD nations. We have seen too clearly the consequences when societies lack horizontal and vertical trust.

Even in post-conflict communities such as Nicaragua and in impoverished communities in South Africa, systemic interventions can create higher levels of social capital. Through investment in bottom-up, community-driven programs such as Japan's Ibasho program, residents and neighbourhoods can build social capital and resilience against future shocks. Through constructing and upgrading public-use facilities and through supporting non-government organisations and civil society organisations, there can be better preparation for shocks to come. EAFO

Daniel P. Aldrich is Director of the Security and Resilience Studies Program and Professor of Political Science and Public Policy at Northeastern University. 


\section{A new mantra for Japanese disaster management}

JUSTIN WHITNEY

\section{I} N THE aftermath of the devastating March 2011 Tohoku earthquake, tsunami and nuclear power disaster (commonly referred to as 3.11), Japan's overwhelmed bureaucrats realised that disaster management planning had to change. Rethinking the assumptions that underpinned disaster planning affected every facet of official preparation for the next calamity. In a nation famous for communal cohesion, the role of the individual and self-help have become the mantra for disaster first response.

The assumptions were that public administrators, formal emergency responders, and robust infrastructure would enable the nation to cope with a major disaster. These assumptions arose out of the aftermath of the 1995 Great Hanshin-Awaji earthquake, when Japanese bureaucrats and politicians were severely criticised

\section{Aware of their limitations} following a catastrophe, all tiers of government reimagined their emergency management role as providers of information to individuals and groups for their poor planning and belated response to that disaster. Government responded to those failures by shifting existing policy and legal structures, investing heavily in overhauling and strengthening much of the nation's emergency management arrangements. But the limitations of government itself were not readily acknowledged.

While policymakers recognised the important role of volunteers and volunteer groups in augmenting the government response in the aftermath of the 1995 event, 3.11 highlighted just how limited the government remained in its ability to cope with calamity. In the immediate wake of 3.11-as radioactive clouds threatened to approach greater Tokyo-officials realised the seriousness of the situation. Former Japanese prime minister Naoto Kan acknowledged that had an evacuation order been called, it would have entailed the impossible task of relocating 50 million people-almost half the population of Japan.

Compounding the situation was the impact that the 3.11 calamity had immediately on Tokyo. The nation's largest city was effectively paralysed. More than five million workers in Tokyo became kitaku nanmin (refugees unable to return home) due to power outages, public transport disruption and severe traffic jams. Those who were able to walk home did so. Others remained in their offices or attempted to crowd into train stations.
3.11 ultimately swept away a government-centric approach to disaster response. It was clear that disaster planning was not fit for purpose, especially when a city like Tokyo was its locus. Triggered by this sobering realisation, the government sought to plug its capability gap through an unprecedented drive to harness all aspects of society. A threeword mantra coined before 3.11-jijo, kyōjo, kōjo (self-help, mutual help and government help)-became the central concepts of emergency management planning thereafter.

For a nation described as a 'managerial state' and one known for its communal cohesion, the prioritisation of self-help (jijo) within this mantra was a fundamental shift. A prime example of this was the colossal undertaking by the Tokyo Metropolitan Government in 2015 to provide every residence in its jurisdiction with a hard copy of Tokyo Bōsai (Tokyo Disaster Prevention), a 321-page guidebook filled with simple strategies and illustrations that aimed to enhance household and individual resilience. Strikingly, the guide almost completely omits mention of government help $(k \overline{o j o})$.

The freely downloadable Tokyoto Kitaku Kon'nansha Taisaku Handobukku (Tokyo Metropolitan Handbook for Persons with Difficulty Returning Home) was developed in 2012 and subsequently updated by the national and Tokyo Metropolitan governments to provide a similar 


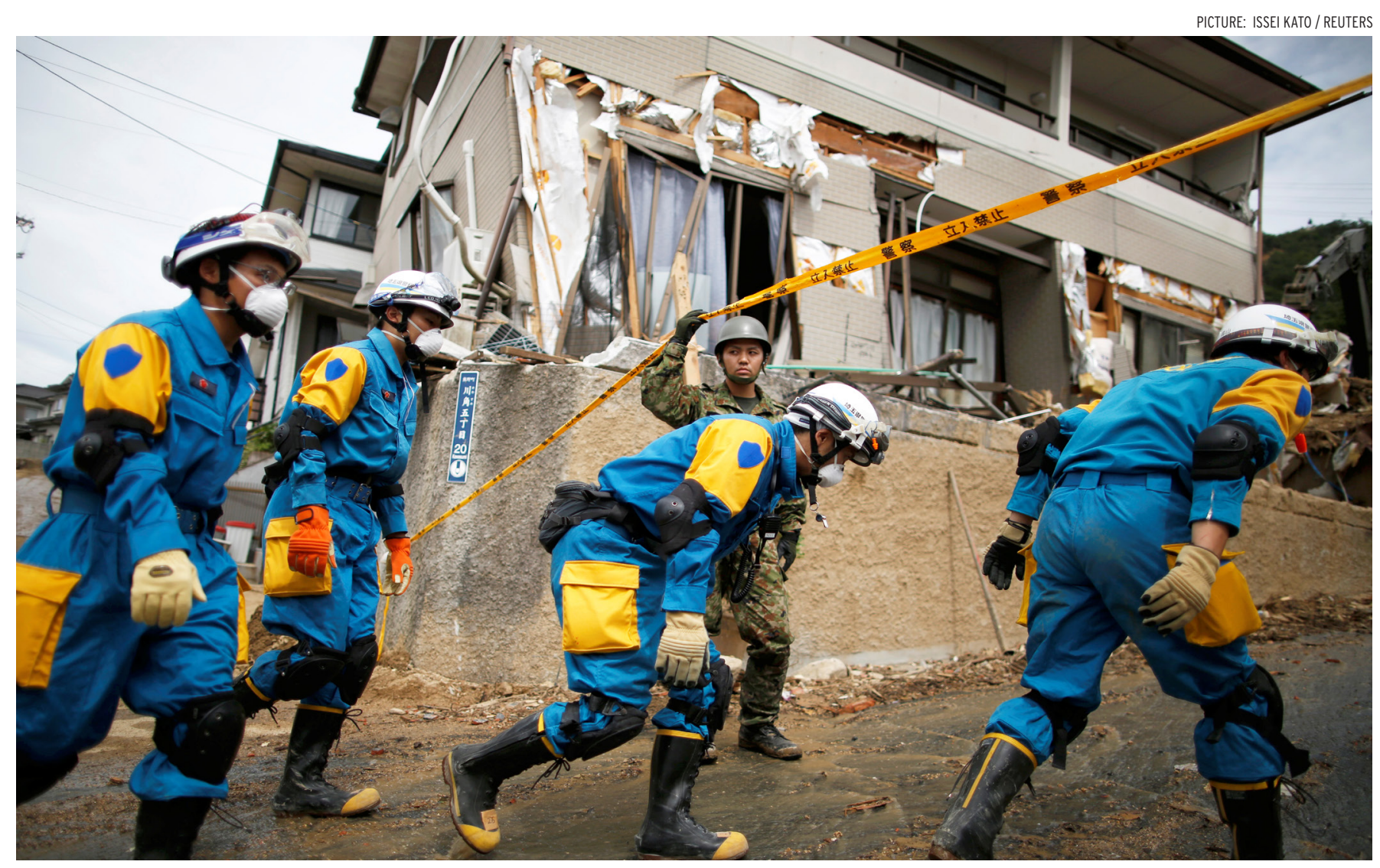

Rescue workers and Japan Self-Defenses Force soldiers search for missing people at a landslide site in Kumano Town, Hiroshima Prefecture (July 2018).

message. The handbook stresses that rather than relying solely on the government to develop policies for disaster response, society as a whole needs to contribute to the development and promotion of measures (jijo and kyōjo).

Aware of their limitations following a catastrophe, all tiers of government reimagined their emergency management role as providers of information to individuals and groups so that they would be better able to help themselves and each other. The term jōhō nanmin (information refugees) became a key focus of government policy.

The notable related policy, the national Jōhō Nanmin Zero (Zero Information Refugees) strategy, was launched in December 2016. It aimed to ensure the adequate delivery of information to vulnerable parts of Japanese society during emergencies, including the elderly, foreign residents and tourists. The comprehensive strategy spans multiple policy domains-accessibility, multiculturalism, tourism, aged care and digital communications-but focuses largely on the individual through the provision of information to facilitate self-help (jijo).

Japanese politicians are increasingly leveraging the self-help mantra to drive innovation across other policy domains. On 6 September 2020 Prime Minister Yoshihide Suga delivered his inaugural press conference and reflected on those affected by the series of natural disasters that had impacted the nation over 2020. In closing, Suga described his vision for Japan by calling for the cooperation of Japanese citizens to build a society based on jijo, kyōjo and kōjo, and promoting the concept of kizuna (societal ties), another term made popular in the aftermath of 3.11.

Despite echoing this mantra made popular following calamity as a rallying cry to the nation, the inclusion of kizuna may be just a smokescreen. Greater importance has been placed on the individual in Japan's community resilience-building strategy-an emphasis that parallels a growing belief within Japanese society that selfhelp is more important than mutual and government help.

The new strategy makes complete sense, when official response mechanisms are overwhelmed in the immediate aftermath of a disaster. However, the emphasis on the individual, now permeating other policy domains, might be a step too far. This concept creep has resulted in critics claiming that it is nothing 


\section{EMERGENCY POWERS}

more than the government attempting to shirk its responsibilities. There is a risk that blurring these concepts across policy domains may dilute their effectiveness when it really matters. Their misuse may result in the population becoming desensitised to their original meaning, undermine trust in government and deter people from coming together to assist each other in times of calamity.

Striking a balance between the roles and responsibilities of government and the individual will continue to challenge policymakers. Risk associated with desensitising the population to these concepts through over-exposure and concept creep also needs consideration.

The question is whether this greater emphasis on the individual can fill the capability gaps of government in the next response to a calamity. A typical response by Japanese policymakers when asked perhaps sums up the reality: Okiteminaito wakaranai, we won't know until the next one happens. EAFQ

\section{Dr Justin Whitney is a graduate of} The Australian National University and is a Research Fellow at Nagoya University, Graduate School of Law. The support of the Australia-Japan Foundation is acknowledged for funding the research underpinning this paper.

EASTASIAFORUM OUR NEXT ISSUE ...

\section{Project Korea}

www.eastasiaforum.org

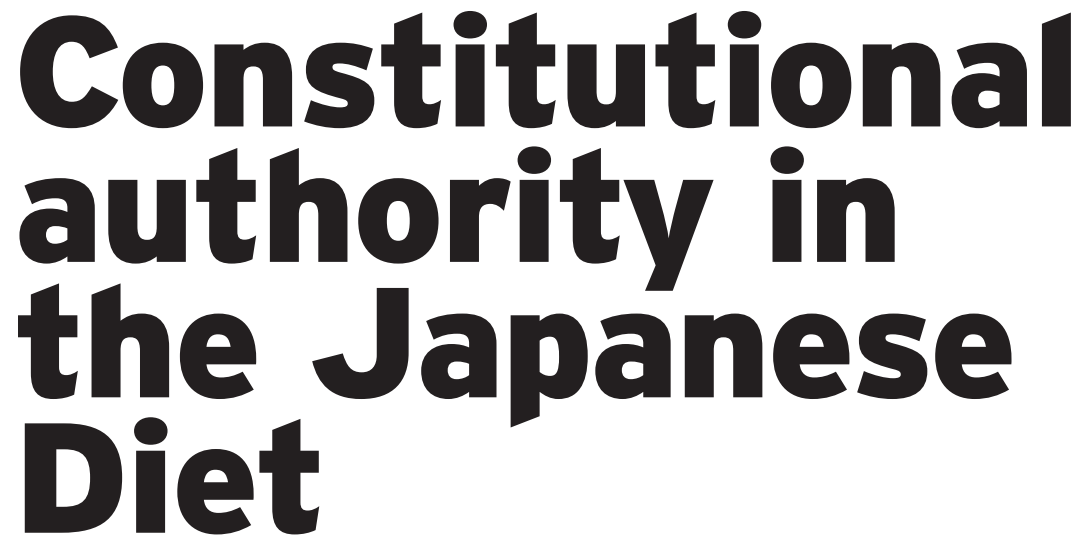

LAWRENCE REPETA

N THE early days of the

COVID-19 pandemic, while government authorities in many countries issued mandatory lockdown orders backed by penalties for noncompliance, Japan's government did not. In March 2020, the Diet passed an amendment to the infectious disease control law that added COVID-19 to diseases that were covered but did not provide penalties for noncompliance with government requests to limit activities. International news organisations reported that Japan's Constitution 'would need to be amended to impose and enforce a lockdown'.

The suggestion that effective action required constitutional change was no surprise. The Liberal Democratic Party (LDP) has been calling for change to the democratic Constitution since it was founded in 1955. One key proposal is the creation of an 'emergency powers' provision. But while the pandemic is a crisis that calls for emergency action, an effective response does not require constitutional change.

Article 41 of Japan's Constitution makes the Diet 'the highest organ of state power' and the 'sole law-making organ of the state.' The Diet holds the power to pass laws that limit individual freedoms to protect public health. It has done so many times. The infectious disease control law and the mental health law provide power for mandatory examinations and hospitalisations. Following the 2011 nuclear meltdown at Fukushima, then prime minister Naoto Kan issued a mandatory evacuation and other orders based on laws that grant such power.

With COVID-19 case numbers on the rise and new variants spreading, the Diet revised the infectious disease law again in February 2021. This time the revision did provide for mandatory orders backed by penalties, albeit relatively small ones. Under one provision, restaurants and bars that do not follow orders to reduce operating hours can be fined up to 300,000 yen (US\$2700).

This provision was challenged in court six weeks later. The plaintiff is the popular restaurant chain Global Dining, which received an order from Tokyo Governor Yuriko Koike to close its restaurants by $8 \mathrm{pm}$ each night. The company president declared that the order violated his right to free expression and his company's right to do business. 


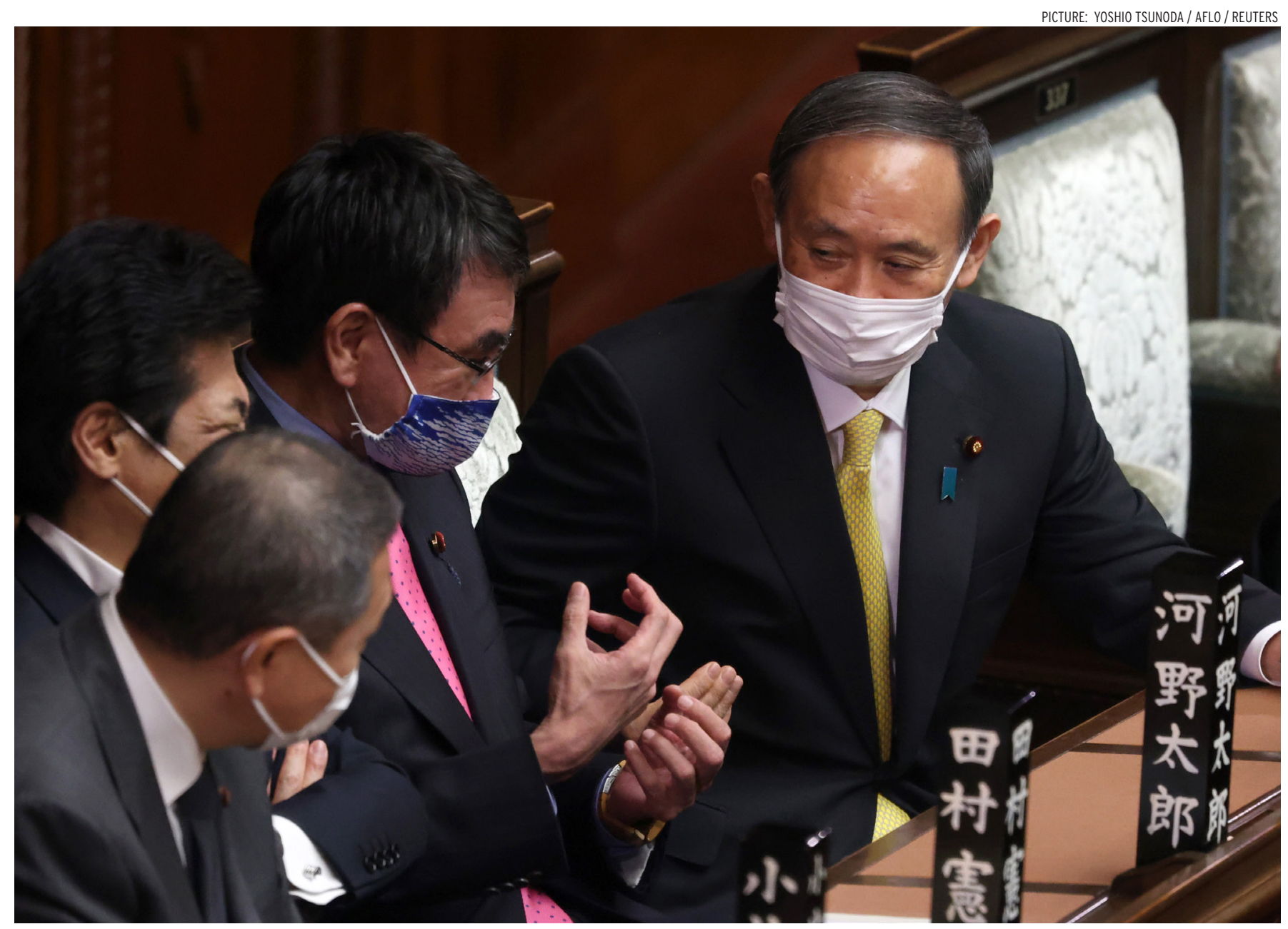

Prime Minister Yoshihide Suga speaks with cabinet members at a Lower House plenary session of the National Diet in Tokyo (11 May 2021).

There are two readily apparent constitutional claims available to Global Dining and other potential plaintiffs. The first is that Governor Koike's order improperly restricts constitutionally protected freedoms, including the right to do business. This claim is unlikely to succeed because the Diet holds the broad power described above and Japan's courts rarely overturn Diet action.

In more than seven decades of interpreting the Constitution, the Supreme Court has held legislation unconstitutional on only 10 occasions. When the Court turns away challengers like Global Dining, it frequently rules that legislation serves the 'public welfare' under Constitution
Article 13 and is therefore acceptable. It's hard to imagine a more important public welfare interest than protection from infectious disease.

Another potential claim is based on Constitution Article 29(3), which requires the government to pay compensation when it confiscates private property. But the standard interpretation of Article 29(3) requires compensation only when specific parties are affected by government action, not in cases like infectious disease control where measures affect a broad spectrum of society.

In comments made on 3 May 2021, Japan's Constitution Day, Prime Minister Yoshihide Suga suggested that the government needs constitutional emergency powers to effectively address crises like COVID-19. His words fit with many other LDP demands for constitutional change. The Party's comprehensive proposals issued in April 2012 include an entirely new provision that would grant the prime minister power to declare an emergency in an extremely broad range of circumstances.

Since 2016, the LDP has included 'emergency powers' among the four constitutional proposals of utmost priority. COVID-19 pushed it to the top of the list.

Continued advocacy for constitutional change by LDP leaders is having an effect. On 1 May 2021, Kyodo News reported that more than 


\section{DEMOGRAPHIC DECLINE}

half its survey respondents believe Japan must add an emergency clause to the Constitution to better respond to COVID-19 and other disasters.

The notion that governments should have emergency powers to deal with crises makes common sense. In Japan's case, the Diet has passed several laws that grant such powers to the executive offices of government for use in defined circumstances. The primary effect of the LDP's constitutional proposal would be to reallocate this authority from the Diet to the Cabinet itself, which could draw directly on constitutional power to declare emergencies and then issue orders with the force of law. Unlike the Diet, which generally operates in the open and allows the participation of opposition party members, the Cabinet works behind closed doors and ordinarily excludes the opposition. Granting independent constitutional authority to the Cabinet as the LDP proposes would promote secrecy and could become the first step towards establishing authoritarian government.

With big majorities in each house of the Diet, the LDP-Komeito alliance holds the power to pass whatever legislation is necessary to authorise effective government action in an emergency. The important question posed by the pandemic does not concern the Constitution-it is why Japan's leaders have been so reluctant to employ the power they already hold through the parliament. It seems that the prime minister and others seek to deflect attention from the proper focus on this question. EAFQ

Lawrence Repeta, formerly Professor of Law at Meiji University, is a retired lawyer and business executive.

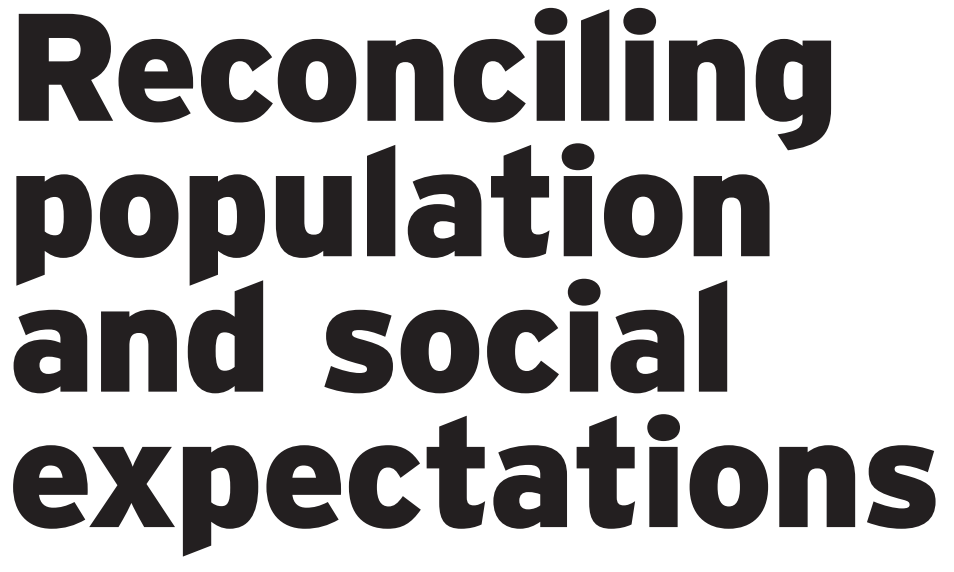

CHELSEA SZENDI SCHIEDER

J APAN has been declared the world's first 'super-aged' society and a 'pioneer shrinking society', rapidly inverting the demographic pyramid upon which the modern state has been built. Since 1989, when the low fertility rate of 1.57 became a major social concern, numbers have continued to trend downward. In June 2020, the Japanese government announced the preliminary results of the 2020 census revealing that the number of births in that year was the lowest on record.

Government efforts since the mid1990s have focused on encouraging women to have more children. However, even if every woman capable of doing so gave birth to three children in the next few years, it would not solve the economic and social effects of this ongoing 'baby bust', namely Japan's labour shortages and the pressing burdens of pensions and elderly care in the near term. It would aggravate rather than address the larger crises associated with urban crowding and ecological devastation. In this piece, I try to analyse the current demographic crisis beyond the narrow confines of many of the pronatalist policies already implemented, arguing that the road ahead leads into unexplored territory, requiring flexible and creative plans to navigate it.

The 1995 Angel Plan and the 1999 New Angel Plan focused on supporting women who wanted to continue to work while raising children. But urban day care centres still have long waiting lists that force parents-overwhelmingly mothersto forgo work. Policies focused on encouraging women to work more ignore the 'second shift' of domestic work that often falls to women. The Japanese economy depends heavily on women's unpaid care work in the home. There is also evidence that it has not been women's preferences but general economic insecurity that has depressed the birth rate.

Coupling and childbearing in Japan is bundled with a host of social demands around heterosexual marriage, gendered divisions of labour and sacrifices at both work and home. This sets an impossibly high hurdle for many potential parents, especially in the precarious 'lost decades' since Japan's economic bubble burst in 1991.

Young people in Japan today are trapped in social systems forged by earlier generations under very different circumstances, while the 


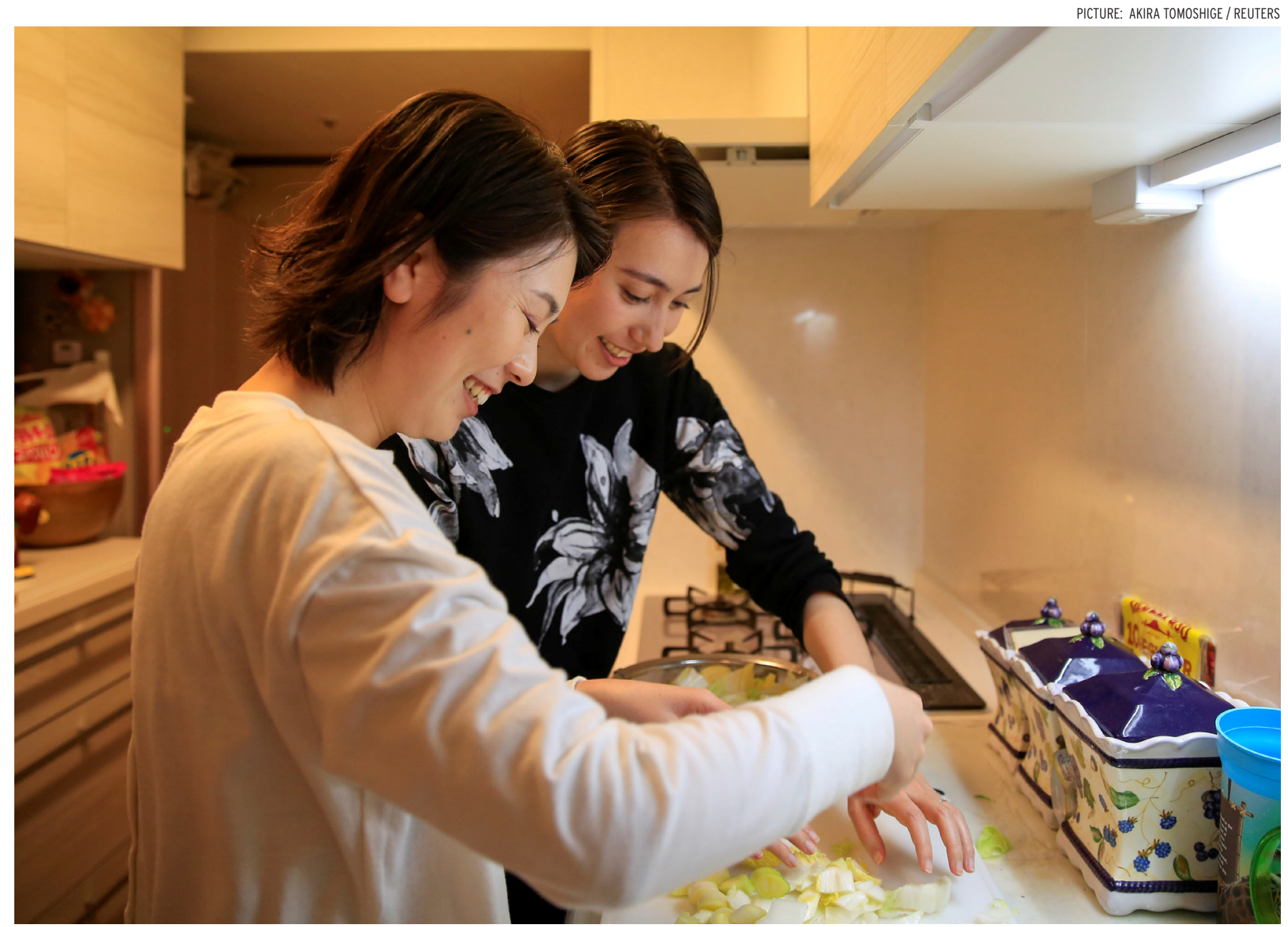

Despite public opinion shifting significantly in favour of same-sex partnerships, the current government stance still only allows for one kind of family.

benefits of meeting these older social expectations aredAritartain. Practices established in the mid-20th century to manage an affluent society cannot address the problems of world today.

Working with young university students, I see how they are struggling to meet social and economic expectations developed under very different historical circumstances. They tend to interpret any inability to meet certain pre-existing benchmarks associated with becoming an adultemployment, marriage, for exampleas personal failures and feel politically powerless. A 2009 poll conducted by the Japan Youth Research Institute found that few young Japanese feel empowered to change their circumstances: about 68 per cent of Japanese high school students do not believe that their actions can change the aspects of society that they would like to change.

If young people could be empowered to demand what they need to form the kind of families they want, it would shift the understanding of what constitutes family structure and alleviate individual childcare burdens. The ongoing 'baby bust' is already a collective indictment of the current system. As Jenny Brown argues in the case of the United States, a dropping birth rate can be read as a kind of 'birth strike.' The issue then becomes how to articulate individual choices into collective demands.
Some government initiatives have attempted to harness individual dissatisfaction with existing social pressures to revitalise rural regions hit hard by Japan's demographic implosion. Susanne Klien's interviews with young urban migrants to rural areas reveal that many see their move as less risky than maintaining their status quo. This trend requires a shift in mainstream concepts of success, for example away from demanding jobs in urban areas considered prestigious. But, as Klien notes, policies that emphasise individual actions as solutions obscure the government's responsibility for creating such a profound socioeconomic gap between outer regions and urban centres. 
The government could do more to shift the understanding of what constitutes responsibilities within a family, and the definition of family itself. The June 2021 Japanese Supreme Court decision upholding a law that forces married couples to share a surname-a law no other country has-is generally unpopular. Public opinion in favour of samesex marriage also differs from the government's stance. While samesex partnerships are recognised in some areas, adoption is still out of the question for same-sex couples. Japan still only allows for one kind of family.

The demographic crisis presents a provocative challenge to definitions of a healthy society and economy, that enjoys both demographic and economic growth. 'De-growth' may be the best option to mitigate the ecological cost of decades of rapid growth. Some observers in Japan have attempted to adopt a positive view of demographic decline, particularly in rural areas, employing terms like 'creative depopulation' (sōzōtekina kasoka). Still, it is difficult to know how many shrinking regions can replicate the few celebrated success stories of rural rejuvenation.

Along with urban to rural migration, Japan will also need to grapple with immigration. Many pronatalist arguments have framed increased immigration as an impossibility because of popular unpopularity, but opinion polls show that the Japanese population is not categorically opposed to immigration or immigrants. Immigration can alleviate short-term labour shortages, and to be sustainable will require clear communication and support.

In short, the solution to Japan's demographic crisis will need to be an imaginative policy mix. The demographic crisis may offer an opportunity to interrogate the premise of never-ending growth upon which many modern societies are constituted.

Policies will need to embrace new beliefs about the value of care work, the meaning of family, and the opportunities of 'de-growth'. Those guiding policy will need to account carefully for the actual lived economic, social, and ecological realities of young people in Japan and around the world. For this to happen, young people will need to become more empowered, even if they remain outnumbered. EAFO

\section{Chelsea Szendi Schieder is a historian and Professor in the Department of Economics, Aoyama Gakuin University, Tokyo.}

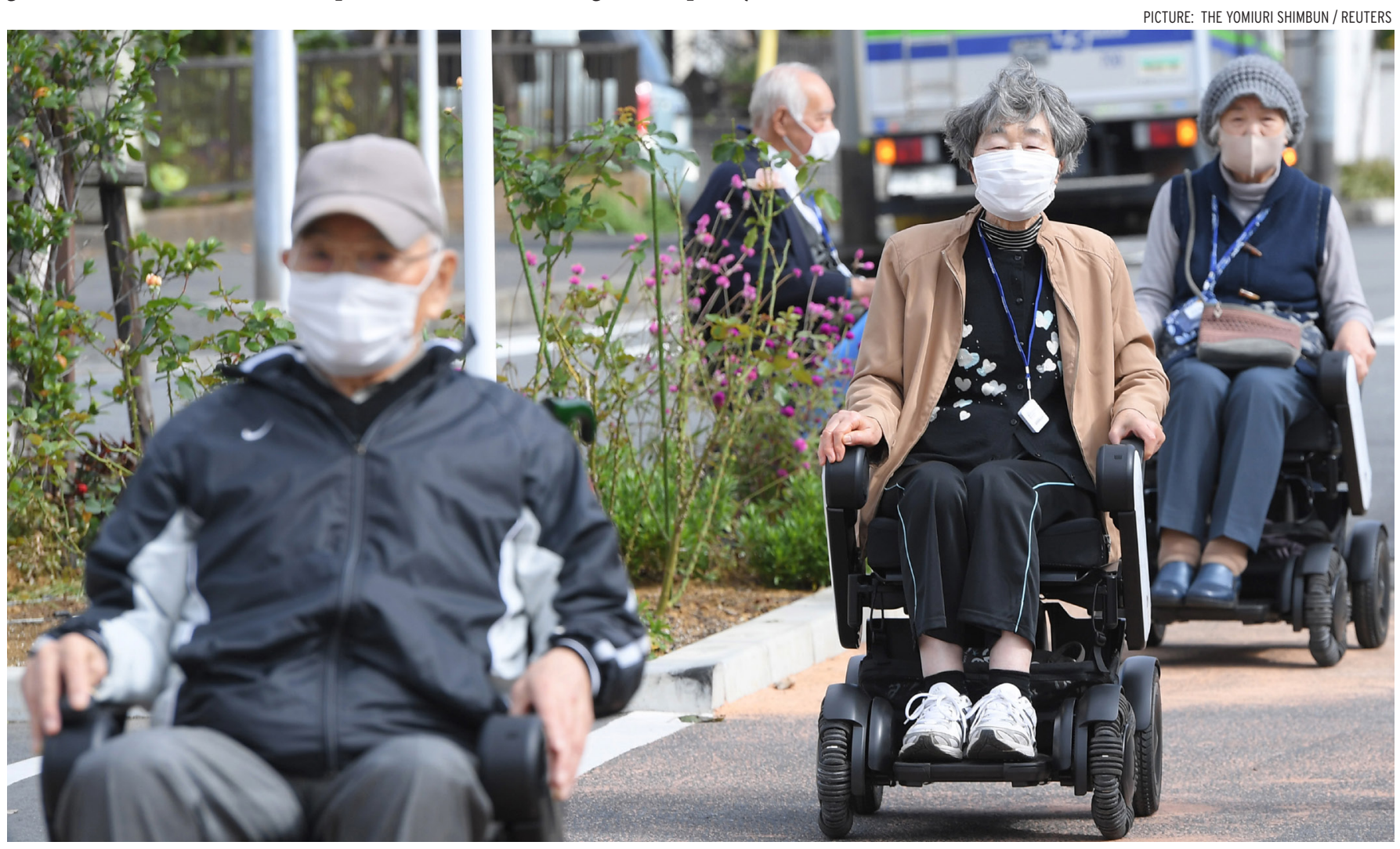

Japan has been declared the world's first 'super-aged' society with a birth rate decline that has been trending downwards since 1989. 


\section{LDP dominance still cripples Japanese democracy}

JIRO YAMAGUCHI

$\mathbf{T}$ HE Liberal Democratic Party

(LDP) has long dominated Japanese politics, losing power on only two occasions since 1955. But despite this dominance, it has not necessarily been easy for LDP prime ministers to implement key policies. At least until the mid-1990s, a series of check-andbalance mechanisms embedded in the party and the bureaucracy prevented them from doing so.

First, there are competing factions within the LDP. With constant factional competition for party leadership, non-mainstream politicians in the party took advantage of the mismanagement and corruption of those holding top party positions to seek intra-party regime change. This 'pseudo-change of power' within the LDP brought about policy shifts, preventing continuity. Kakuei Tanaka achieved rapprochement with China, for example, after defeating conservative Takeo Fukuda in the LDP presidential election in 1972.

Second, the bureaucracy was characterised by the vigorous independence of each ministry. Turf-minded bureaucrats, essentially responsible for policymaking, maintained a strong 'vertically siloed administrative system'. Ministries pursued their own interests over broader public interests, resulting in a lack of national strategy.

Lastly, the Cabinet Legislation Bureau-a neutral institution esteemed for its expertise-served as the guardian of the law by reviewing bills to be submitted by the Cabinet while interpreting the Constitution. In particular, the Bureau was instrumental in putting a brake on security policies that were not consistent with war-renouncing Article 9 of the Constitution.

In the 1990s the LDP was toppled from power temporarily and institutional reforms were carried out across both the electoral and administrative systems. The LDP and other political forces shared the objective of seeking more reliable and healthy politics.

Twenty-five years have passed since the single-seat constituency system was introduced in Lower House elections, along with the political party subsidy system. These reforms significantly changed how LDP politicians now behave.

Traditionally, politicians won Lower House elections by personally organising their own supporters and collecting their own political fundsgiving them a degree of independence from the party leadership and authority. Now, LDP and other politicians rely heavily on the subsidy paid by the government to political parties and distributed to each politician by party headquarters. The LDP leadership also officially endorses candidates running on the LDP ticket, wielding increased authority over members. This constrains the amount of intra-party factional fighting and debate over policies.

Former prime minister Ryutaro Hashimoto also implemented administrative reforms during this time in office. To strengthen the political leadership and coordination functions of the prime minister's office, the Cabinet was reinforced with increased staff, while central ministries and agencies were streamlined. Staffed with bureaucrats recruited from major ministries, the Cabinet Secretariat and the Cabinet Office now set the agenda under the initiative of the prime minister. Junichiro Koizumi was the first prime minister to fully utilise the results of those institutional reforms in the early 2000s, promoting policy changes such as the privatisation of postal services.

Prime minister Shinzo Abe made use of a considerably more centralised LDP and government. Abe's approach is characterised by his intervention

The dominance of power

by the LDP brought

about the collapse of

healthy parliamentary

deliberations based on

careful argument 


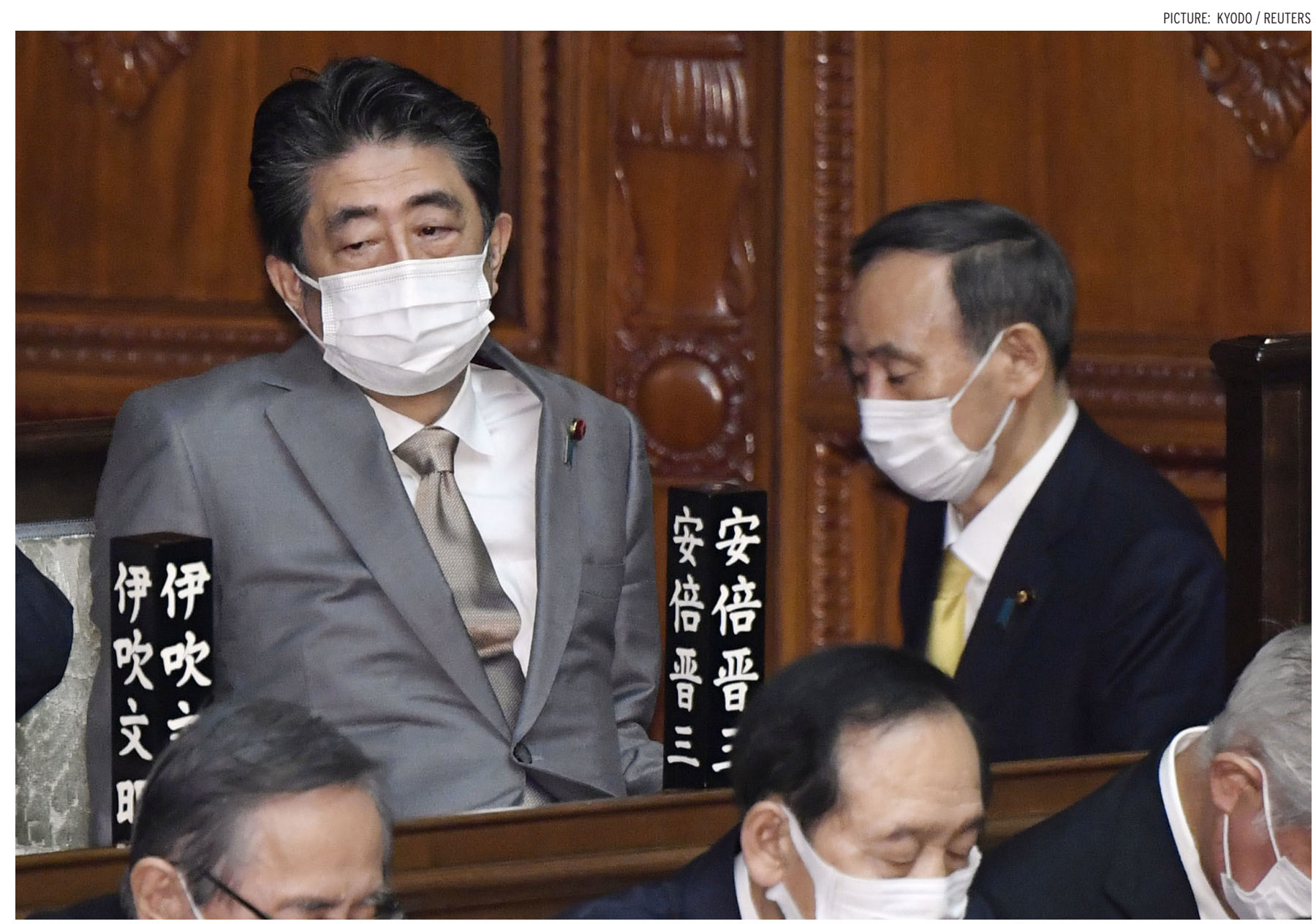

An overwhelming majority in the Diet guarantees success for LDP leaders such as Prime Minister Yoshihide Suga, and his predecessor, Shinzo Abe (January 2021).

in the appointment of key posts in specific agencies previously known for their well-entrenched independence, thus, placing them under political control. Particularly striking was Abe's violation of the independence of the Cabinet Legislation Bureau, which was forced to change its interpretation of Article 9 to pave the way for the enactment of security legislation.

A strong opposition is indispensable to ensure contestability through the possibility of a change of power as a counterbalancing force against a powerful ruling party. But after two brief periods in power, no major reorganisation of opposition forces has been achieved so far. With average voter turnout in national elections languishing at around 50 per cent, the ruling LDP-Komeito coalition wins easy victories.

The dominance of power by the LDP brought about the collapse of healthy parliamentary deliberations based on careful argument.

Parliamentary debate became a political farce because everyone knew that the majority held by the LDP-led coalition meant that they had everything under their control. This enabled the Abe administration to enact a series of constitutionally questionable bills. When allegations of political corruption involving Abe and his wife unfolded, government officials refused to provide explanations in good faith when questioned by the opposition. Meaningful debate between the government and opposition in the Diet now seems impossible.

Government officials, including the prime minister, are rarely held responsible for their actions despite the enormous power they enjoy. Japanese courts are reluctant to scrutinise the constitutionality of specific legislation, and rarely annul government policies as unconstitutional. The government denies the significance of the Diet and does not fulfil its accountability obligations in sincere debate.

Government officials often survive corruption scandals as major newspapers and TV stations fail to hold the government to account, scandals which produce only a temporary decline in approval rates. 
An irresponsible government means increased abuse of power and a decline in policymaking capacity. Bureaucrats in charge of policymaking are more obedient to those holding power for reasons of self-preservation and career advancement and avoid providing advice that might offend their political bosses. These same bosses attempt to achieve self-serving policy goals without sufficient elaboration and explanation in the Diet.

This is why the Japanese government continues to drift in the face of the difficult challenges caused by COVID-19, including how it dealt with the Tokyo Olympic Games. Japan saw four waves of COVID-19 in a year and a half. As of August 2021, the total death toll was over 15,000. These numbers are smaller than those of some European countries and the United States, but about three times those of South Korea and Australia.

The number of COVID-19 tests that have been performed in Japan is still relatively low, and the isolation of infected persons is not being managed properly. In the last quarter of 2020, when the number of infected people decreased temporarily, the government implemented a nationwide subsidy program to encourage people to travel and eat at restaurants. The GoTo Travel campaign ended up spreading the infection across the country as medical experts predicted.
Reckless policies, including the holding of the Olympics despite the pandemic, blatantly ignore scientific knowledge and disregard informed criticism. The government led by Prime Minister Yoshihide Suga appears in control because of its overwhelming majority in the Diet. But whether under Suga or his successor, the threat to Japanese policy capacity and the functioning of democracy appears real, as more immediately, does that to the lives of many Japanese people. EAFQ

Jiro Yamaguchi is Professor at the Faculty of Law, Department of Political Science at Hosei University.

\section{ROYAL REFORM}

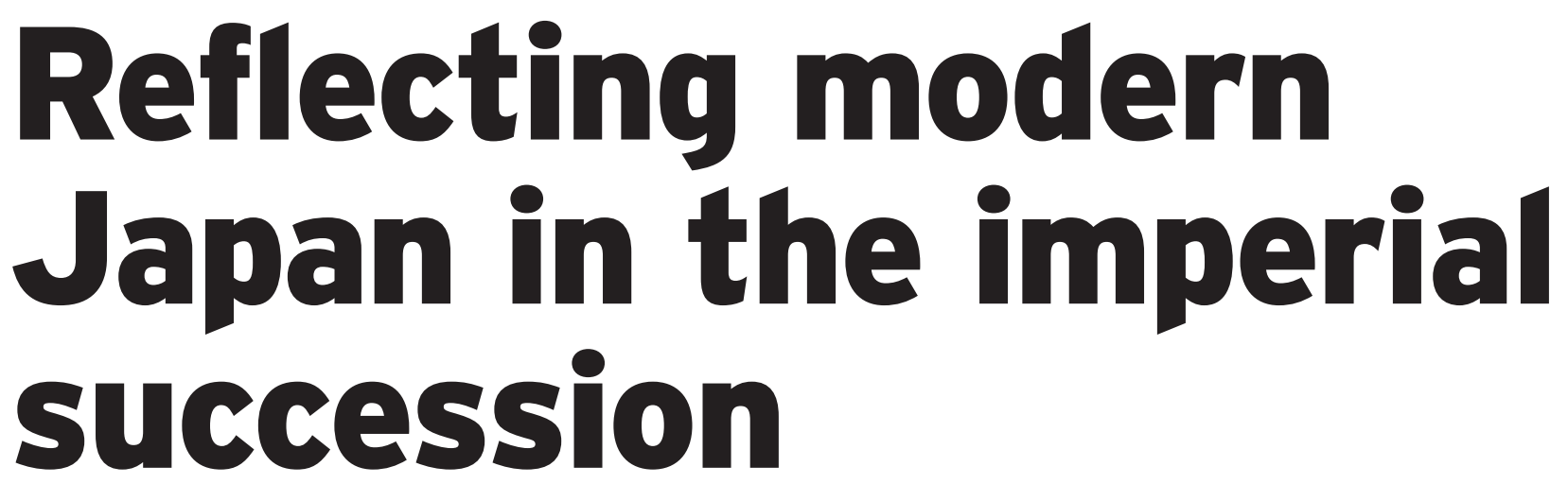

KUMIKO NEMOTO

A S IN ancient Rome, where the adoption of a male heir in favour of a female successor was common, Japan is likely to rely on adoption to preserve the male line of succession to the Chrysanthemum Throne. The possibility of an empress in a future Japan may be slim after the June 2021 meeting of experts on the imperial succession. The meeting was convened by Prime Minister Suga, who is said to prioritise preserving the male line to the throne to secure a stable succession.

At the meeting, attendees opposed allowing an empress to take the throne as well as the idea of imperial succession from the matrilineal lineage. This stance was based on the belief that female succession would divide Japan and delegitimise the nature of the imperial system.

The current Imperial Household Law of 1947-an update of the Imperial Household Law of 1889relies on patrilineal lineage, allowing only sons to become emperor, and requiring female members to leave the Imperial Palace after they marry commoners. The expert meeting came 
Conservatives see

\section{the unbroken male}

\section{bloodline as imperative}

\section{to the maintenance of}

\section{the Japanese throne}

up with a two pronged solution to the lack of male successors in the Japanese imperial family: the adoption of a male successor and allowing current female members to remain in the royal family after marriage to commoners so they can assist the emperor.

The adoption proposal has been popular among conservative Diet members. The adoptee would be selected from the eleven former imperial family branches, which were forced to leave the Imperial Household by the United States in 1947.

But the Japanese public is unlikely to be convinced that male succession must be preserved in Japan, when all enlightened European countries have eliminated male-preference primogeniture.

Conservatives see the unbroken male bloodline as imperative to the maintenance of the Japanese throne. They claim that an empress would make Japan's imperial system illegitimate. Some have further insisted on biological essentialism. Others, including members of the media, have expressed strong concerns stemming from patriarchal and nationalistic susceptibilities of a female emperor. They fear that the husband of a future empress could politically manipulate her to take over the entire imperial family.

These views reflect a misogynistic attitude, stereotyping women as incapable and unreliable - they are cast as being the property or objects of male conquest. The commoner fiance of Princess Mako of Akishino, who was seen by many Japanese as unsuitable due to his family background, was introduced as an excuse for not having a female emperor.

In Meiji Japan, the adoption of a male child was common among the $K a z o k u$, an elite class that existed from 1884 to 1947 immediately below the imperial lineage. Adoption was used as a means to continue the elite household - a form of patriarchal unity with a strong emphasis on the family name and property-while women were relegated to bearing heirs. Genealogical, biological, or genetic consistency between adopters and adoptees mattered very little for the Kazoku. Because of huge pressure from the nation and society to sustain the patriarchal house, they relied on less rule-bound types of adoptions, including buying a child from strangers or relying on suppliers in their network of different noble houses.

Bringing back an archaic custom once used for the preservation of the patriarchal line would sacrifice Japan's opportunity to further democratise the meaning of monarchy beyond political divisions and to enhance the support of the public, which is fundamental to the sustenance of monarchy in civil society.

Over 70 per cent of the Japanese public have expressed support for both a reigning empress and emperor of the matrilineal line. There is a large gap between the public's expectations of a globally engaged royal family that serves the Japanese people and the views of conservative traditionalists who insist that the imperial family obey traditional customs and dismiss evolving values and norms.

There are also strong masculinist and nationalistic standpoints among those who oppose female emperors from the matrilineal line. This reflects the patriarchal hierarchy of nineteenth-century Japan, in which women were obligated to serve their husbands' families and families were obliged to serve the state. The Meiji Civil Code defined wives as lacking competence and thus required them to depend on the consent of their husbands on legal matters.

Today, the Japanese people do not look to one-hundred-year-old laws and customs to inform their opinions on the throne. There is overwhelming public support for allowing women to lead Japan's royal family and for an imperial institution that embodies equality and inclusion. Female sacrifice and ambivalence have characterised the Japanese imperial family for too long in postwar Japan. Empress Masako is a Harvard-educated former diplomat whose personal history and marital life mirrors the challenges and structural problems that ordinary Japanese women face. She represents hope for Japan to modernise and evolve so that it can truly embrace and appreciate women with professional achievements.

But these expectations were shattered when she was marginalised

the management of

the Japanese imperial

family must reflect

the views of its largest

stakeholders: the

Japanese public 


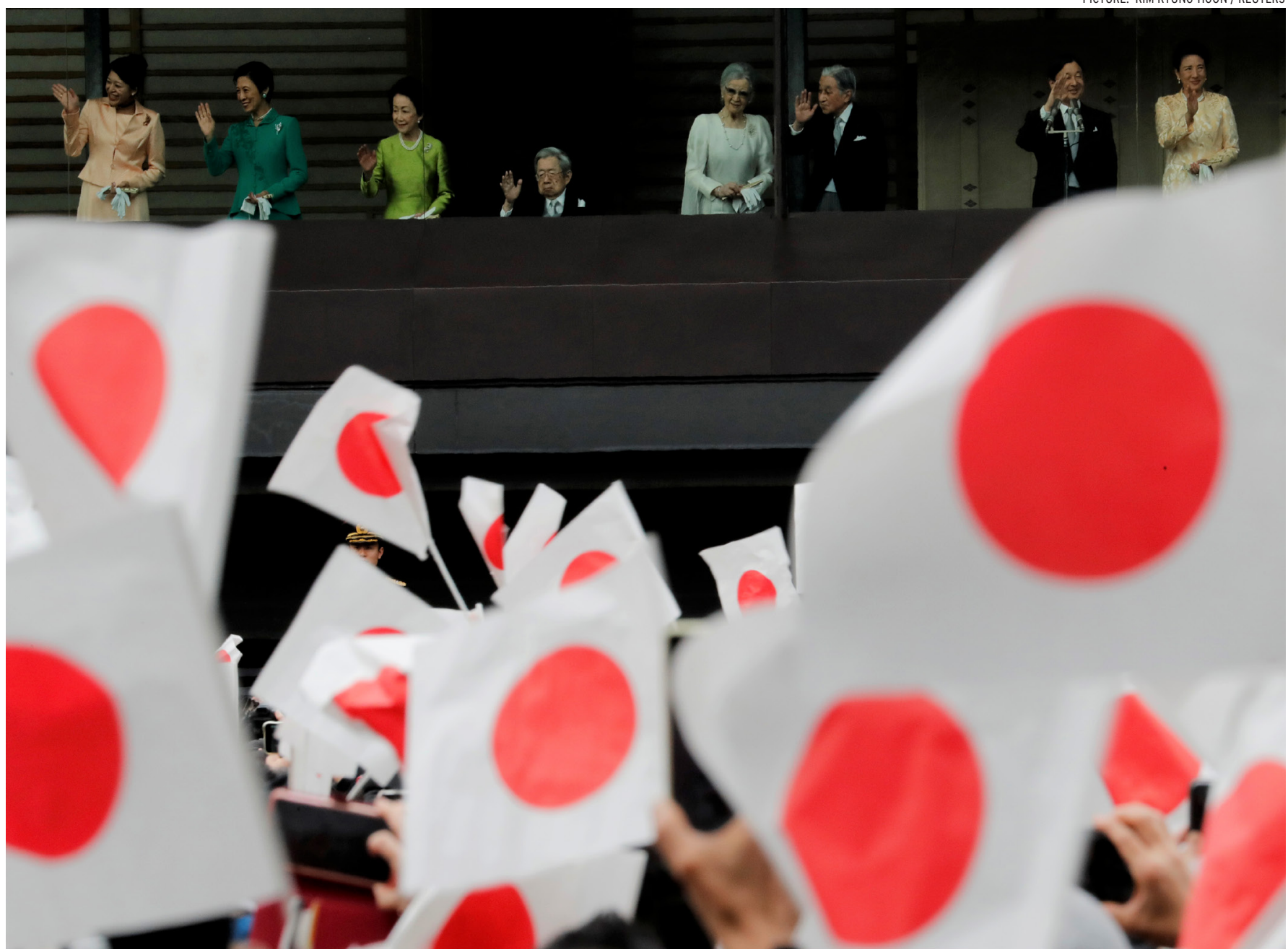

Japan's Empress Emerita Michiko, Emperor Emeritus Akihito, Emperor Naruhito, Empress Masako and royal families wave to well-wishers during a public appearance for New Year celebrations at the Imperial Palace in Tokyo (January 2020).

as a reproductive being struggling with the pressure to bear a male child. Because Japan, like so many other countries, consists of many dualincome families that embrace gender equality, the story of female sacrifice in the imperial family needs to change accordingly.

The British royal family may offer lessons here. The Windsors, a US $\$ 28$ billion royal family, exert a tremendous influence on society and annually contribute hundreds of millions of pounds to the United Kingdom's economy. Members of the British royal family have referred to the institution as a firm, characterised by individual obligations and duties as well as various interpersonal conflicts in response to social pressures. The running of any firm not only comes with fulfilling responsibilities but the expectation that it must please the major stakeholders who support and pay for the business.

Similarly, the management of the Japanese imperial family must reflect the views of its largest stakeholders: the Japanese public. Looking at the British royal family does not mean that the Japanese imperial family ought to engage in the accumulation of wealth but it suggests that public popularity and support are critical to the success of the monarchy. Opening the way for a woman to become emperor broadens the appeal of the imperial family not just to Japanese people but also to the international community.

Much like Japan, the British monarchy faced the challenge of old succession laws, but responded deftly by amending those laws in 2013 so the first-born child of the monarch, regardless of gender, can succeed to the throne. EAFO

\section{Kumiko Nemoto is Professor of} Management in the School of Business Administration at Senshu University, Tokyo. 


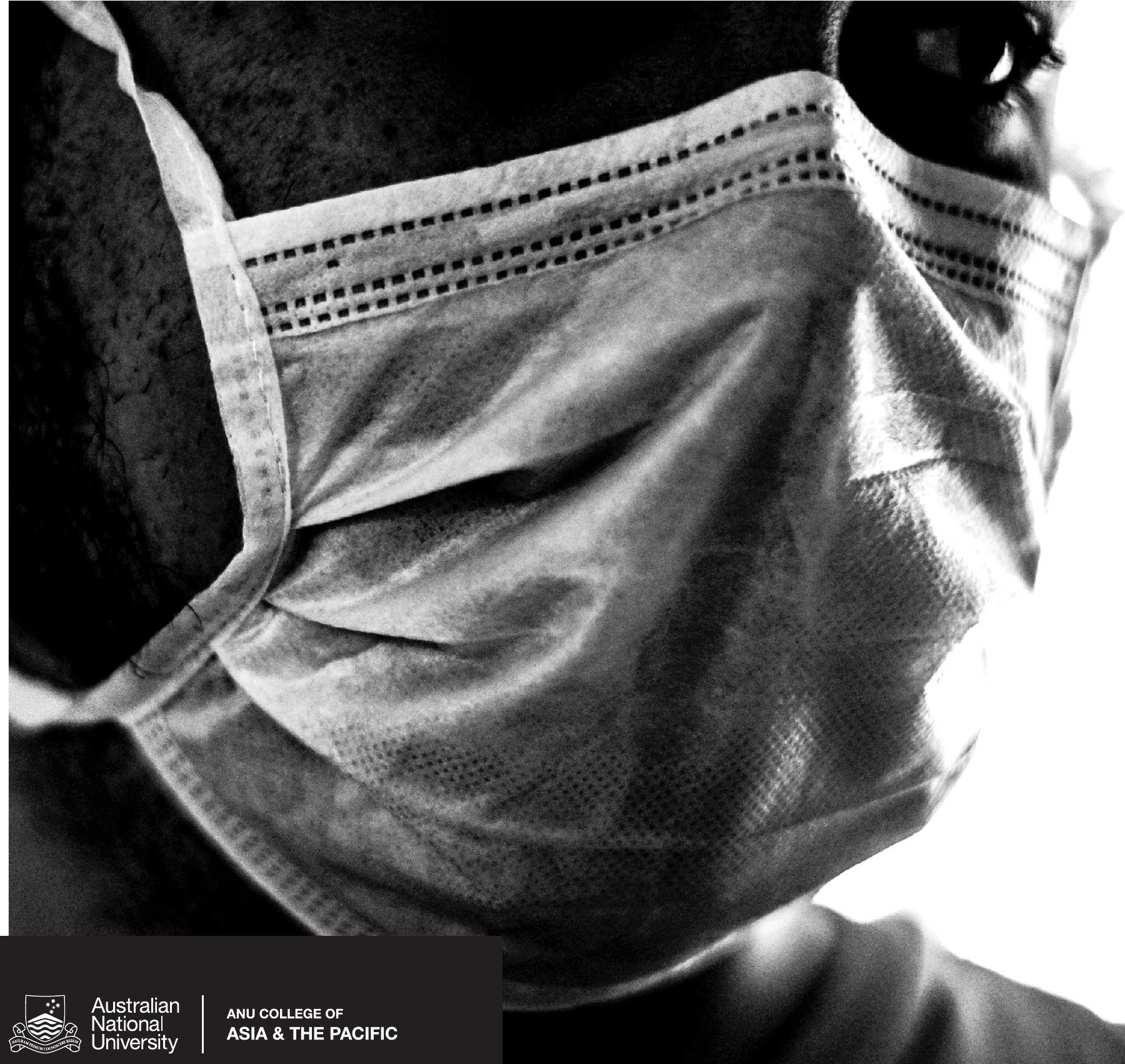

\section{There has never been a more urgent time to use research to shape public debate, policy decisions and the well-being of our society.}

